Runoff Characteristics and Washoff Loads from Rainfall-Simulation Experiments on a Street Surface and a Native Pasture in the Denver Metropolitan Area, Colorado

U.S. GEOLOGICAL SURVEY PROFESSIONAL PAPER 1441

Prepared in cooperation with the

Denver Regional Council of Governments

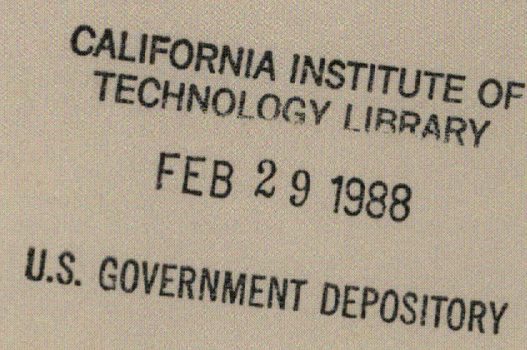




\section{Runoff Characteristics and Washoff Loads from Rainfall-Simulation Experiments on a}

Street Surface and a Native Pasture in the Denver Metropolitan Area, Colorado

By MARTHA H. MUSTARD, SHERMAN R. ELLIS, and JOHNNIE W. GIBBS

U.S. GEOLOGICAL SURVEY PROFESSIONAL PAPER 1441

Prepared in cooperation with the

Denver Regional Council of Governments

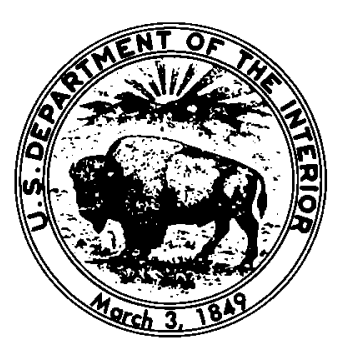




\section{UNITED STATES DEPARTMENT OF THE INTERIOR \\ DONALD PAUL HODEL, Secretary}

\section{GEOLOGICAL SURVEY}

Dallas L. Peck; Director

\section{Library of Congress Cataloging-in-Publication Data}

Mustard, Martha H.

Runoff characteristics and washoff loads from rainfall-simulation experiments on a street surface and a native pasture in the Denver metropolitan area, Colorado.

(Geological Survey professional paper ; 1441)

Bibliography: p.

Supt. of Docs. no.: I 19.16:1441

1. Urban runoff-Colorado-Denver Metropolitan Area. I. Ellis, Sherman R. II. Gibbs, Johnnie W. III. Denver Regional Council of Governments. IV. Title: Runoff characteristics and washoff loads from rainfallsimulation experiments on a street surface and a native pasture in the Denver Metropolitan area, Colorado. VII. Series.

GB991.C6M8?

1986

$551.48^{\prime} 8^{\prime} 0978883$

$86-600105$

For sale by the

Books and Open-File Reports Section

U.S. Geological Survey

Federal Center

Box 25425

Denver, CO 80225 


\section{CONTENTS}

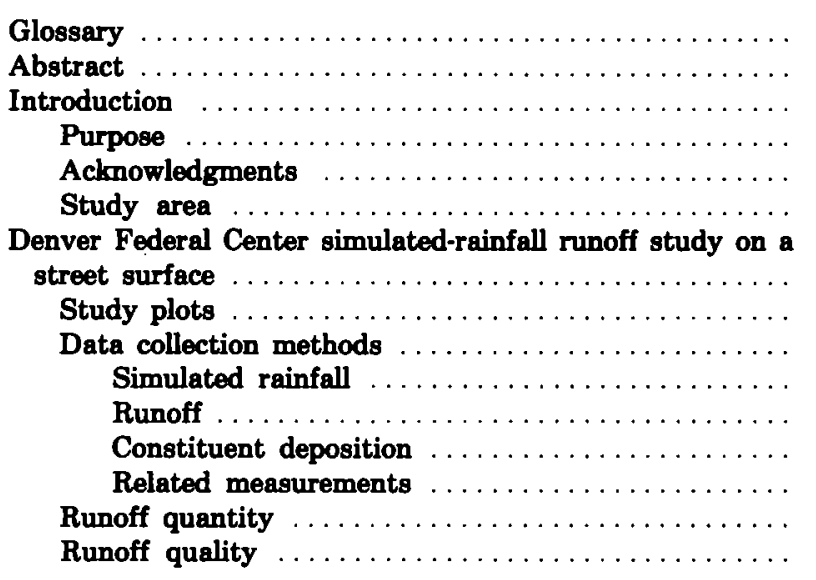

\begin{tabular}{|c|c|c|}
\hline Page & & Pab \\
\hline $\mathbf{v}$ & Denver Federal Center simulated-rainfall runoff study on a & \\
\hline 1 & street surface-Continued & \\
\hline 1 & Constituent deposition and washoff loads & 19 \\
\hline 1 & $\ldots \ldots \ldots \ldots \ldots \ldots$ & \\
\hline 2 & Rooney Ranch simulated rainfall-runoff study on a native & \\
\hline 2 & 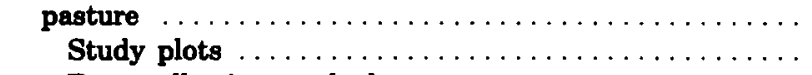 & \\
\hline 3 & Data collection methods & \\
\hline 3 & Simulated rainfall & \\
\hline 3 & Runoff & \\
\hline 3 & Soil moisture & \\
\hline 5 & Runoff quantity & \\
\hline 5 & Infiltration rates & \\
\hline 5 & Water-quality relations $\ldots \ldots \ldots$ & \\
\hline 0 & $\ldots \ldots \ldots \ldots \ldots$ & \\
\hline 9 & References & \\
\hline
\end{tabular}

\section{ILLUSTRATIONS}

1. Map showing location of Denver Federal Center study site and Rooney Ranch study site

2. Schematic of the Denver Federal Center plots showing sprinkler and flume locations

3-11. Graphs of runoff and washoff loads of selected water-quality constituents for Denver Federal Center:

3. Plot 1, June 2, 1980

4. Plot 2, June 2, 1980

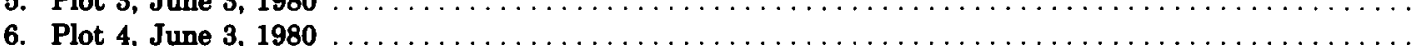

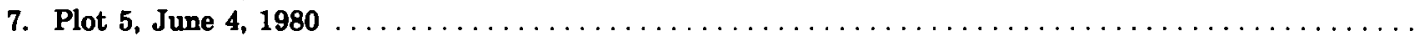

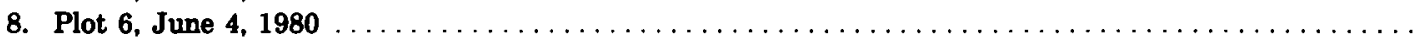

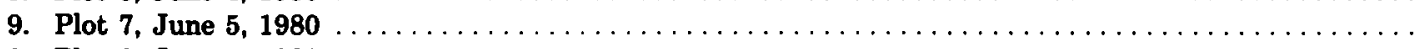

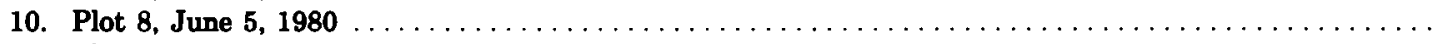

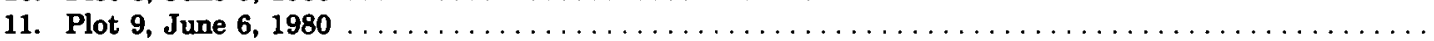

12-18. Graphs showing:

12. Total suspended solids washoff loads and deposition measured by vacuum-strip sampling versus number of days since street washing for the Denver Federal Center plots, June 2-6, $1980 \ldots \ldots \ldots \ldots \ldots$

13. Total lead washoff loads and deposition measured by vacuum-strip sampling versus number of days since street washing for the Denver Federal Center plots, June 2-6, $1980 \ldots \ldots \ldots \ldots \ldots \ldots \ldots \ldots$

14. Total zinc washoff loads and deposition measured by vacuum-strip sampling versus number of days since street washing for the Denver Federal Center plots, June 2-6, 1980

15. Total manganese washoff loads and deposition measured by vacuum-strip sampling versus number of days since street washing for the Denver Federal Center plots, June 2-6, 1980

16. Total nitrogen washoff loads and deposition measured by vacuum-strip sampling versus number of days since street washing for the Denver Federal Center plots, June 2-6, 1980

17. Total phosphorus washoff loads and deposition measured by vacuum-strip sampling versus number of days since street washing for the Denver Federal Center plots, June 2-6, 1980

18. Total organic carbon washoff loads versus number of days since street washing for the Denver Federal Center

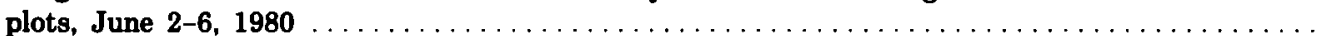

19. Topographic maps of plots 1 and 2 at the Rooney Ranch rainfall simulation site $\ldots \ldots \ldots \ldots \ldots \ldots \ldots \ldots$

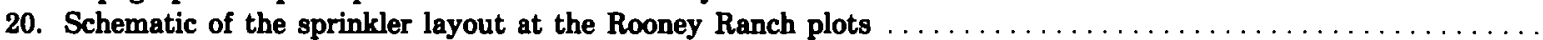

21. Graphs of rainfall, runoff, and infiltration versus time for the simulated rainfall storms at the Rooney Ranch plots,

May 20, 1981 
TABLE 1. Characteristics of simulated rainfall on the Denver Federal Center plots, resulting runoff, and impervious retention

2. Washoff and mean washoff loads of selected water-quality constituents from plots 1-9 at the Denver Federal Center

3. Event mean concentrations of selected water-quality constituents in the runoff from plots 1-9 at the Denver Federal

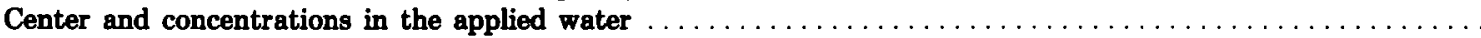

4. Maximum, minimum, and mean event mean concentrations for all storm runoff sampled at station 06711635 North Avenue Storm Drain at the Denver Federal Center, at Lakewood in 1980 and $1981 \ldots \ldots \ldots \ldots \ldots \ldots \ldots$

5. Deposition of selected water-quality constituents measured by vacuum-strip sampling, open-space bucket accumulation, and street-bucket accumulation on the Denver Federal Center plots

6. Correlation coefficients between selected water-quality constituent washoff loads and number of days since street washing. intensity of rainfall, total rainfall, open-space constituent deposition, street constituent deposition, and traffic for the Denver Federal Center plots

7. Antecedent soil moisture, rainfall, runoff, and runoff-to-rainfall ratios for the simulated rainstorms at Rooney Ranch and natural rainstorms at station $\mathbf{0 6 7 1 0 6 1 0}$ Rooney Gulch at Rooney Ranch, 1980 and $1981 \ldots \ldots \ldots \ldots$

8. Soil-moisture and bulk-density data for the Rooney Ranch rainfall simulation plots $\ldots \ldots \ldots \ldots \ldots \ldots \ldots \ldots$

9. Loads of selected water-quality constituents and percentage of loads carried by the first 25 percent of the runoff from

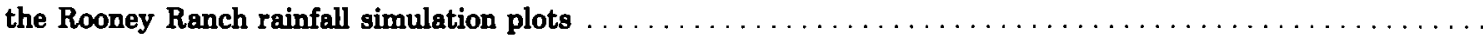

10. Event mean concentrations of selected water-quality constituents in the runoff from simulated rainfall at Rooney Ranch and the range of event mean concentrations in the runoff from natural rainstorms at station 06710610 Rooney Gulch at Rooney Ranch 


\section{METRIC CONVERSION TABLE}

\begin{tabular}{|c|c|c|}
\hline Multiply inch-pound unit & By & To obtain metric unit \\
\hline acre & 4047 & square meter \\
\hline bar & 100 & kilopascal \\
\hline cubic foot & 0.02832 & cubic meter \\
\hline $\begin{array}{l}\text { cubic foot per second } \\
\left(\mathrm{ft}^{3} / \mathrm{s}\right)\end{array}$ & 0.02832 & cubic meter per second \\
\hline cubic inch (in. ${ }^{3}$ ) & 16.39 & cubic centimeter \\
\hline foot $(\mathrm{ft})$ & 0.3048 & meter \\
\hline inch (in.) & 25.40 & millimeter \\
\hline inch per hour (in./hr) & 25.40 & millimeter per hour \\
\hline mile & 1.609 & kilometer \\
\hline part per billion (ppb) & 1 & microgram per liter \\
\hline part per million (ppm) & 1 & milligram per liter \\
\hline pound (lb) & 0.4536 & kilogram \\
\hline pound per acre (lb/acre) & 1.121 & kilogram per hectare \\
\hline $\begin{array}{l}\text { pound per acre per inch } \\
\text { (lb/acre-in.) }\end{array}$ & 0.004413 & kilogram per cubic meter \\
\hline pound per second $(\mathrm{lb} / \mathrm{s})$ & 0.4536 & kilogram per second \\
\hline $\begin{array}{l}\text { pound per square inch } \\
\left(\mathrm{lb} / \mathrm{in}^{2}{ }^{2}\right)\end{array}$ & 6.895 & kilopascal \\
\hline square foot $\left(\mathrm{ft}^{2}\right)$ & 0.09290 & square meter \\
\hline
\end{tabular}

\section{GLOSSARY}

constituent deposition-Material deposited from the atmosphere on the land surface by gravity, precipitation, or wind.

correlation coefficient (r). - A number that expresses the degree of correlation between two mathematical variables. $r=1$ indicates perfect positive correlation, $r=-1$ indicates perfect negative correlation, and $r=0$ indicates no correlation.

event mean concentration - The average concentration of a selected constituent in storm runoff determined as the storm load divided by the storm runoff.

first flush of constituent load-The occurrence of a dispropertionately high portion of a constituent storm load being carried by the first part of the storm runoff. In this paper, a first flush of a constituent load is considered to have occurred if the first 25 percent of storm runoff carries 50 percent or more of the constituent storm load.

impervious retention. - The amount of water falling on impenetrable surfaces that does not runoff. load-The material that is moved or carried by a stream or the quantity of that material in a given time.

moisture retention capability. - The weight of water per unit weight of soil that a soil will hold at 0.22 bars of soil moisture retention force (Miller and McQueen, 1978). It is roughly synonymous with field capacity.

rational method of runoff calculation-Method of determining runoff based on the rational formula. The rational formula states that the peak rate of runoff is equal to the intensity of rainfall times the drainage basin area times a runoff coefficient.

steady-state condition - The condition wherein thstant in magnitude and direction.

Thiessen polygon method-A method of calculating basin rainfall by weighting the rainfall measured at each rain gage by the percent of the basin area which is closer to that rain gage than to any other rain gage.

washoff load - The part of the constituent load carried by the runoff that has been washed off the basin, as opposed to the portion that is present in the runoff due to presence of the constituent in the applied water. 



\title{
RUNOFF CHARACTERISTICS AND WASHOFF LOADS FROM RAINFALL-SIMULATION EXPERIMENTS ON A STREET SURFACE AND A NATIVE PASTURE IN THE DENVER METROPOLITAN AREA, COLORADO
}

\author{
By Martha H. Mustard, Sherman R. Ellis, and Johnnie W. Gibbs
}

\section{ABSTRACT}

Rainfall simulation studies were conducted in conjunction with the Denver Regional Urban Runoff Program to: (1) Compare runoff quantity and quality from two different intensities of rainfall on impervious plots having identical antecedent conditions, (2) document a first flush of constituent loads in runoff from 1,000-square-foot streetsurface plots, (3) compare runoff characteristics from a street surface subjected to simulated rainfall with those from a 69-acre urban basin of mixed land use subjected to natural rainfall, (4) perform statistical analysis of constituent loads in the runoff with several independent variables, and (5) compare the quantity and quality of runoff from 400-square-foot plots of native grasses used for pasture and subjected to simulated rainfall with that from a 405-acre basin covered with native grasses used for pasture and sub-jected to natural rainfall.

The rainfall simulations conducted on the street surface showed that higher intensity simulated rainfall produced a higher percentage of runoff than lower intensity rainfall. A first flush of constituent loads occurred for most constituents in the runoff from most rainfall simulations on the street surface; however, a first flush did not occur in the runoff from simulated rainfall on the pasture. The event mean concentrations of constituents in the runoff from simulated storms on the street surface were generally much smaller than the event mean concentrations of constituents in the runoff from an adjacent urban basin.

Analysis of the data from the rainfall simulations on a street surface indicates that intensity of rainfall and total rainfall are important variables determining constituent loads. The design of the experiment was such that intensity of rainfall and total rainfall were highly correlated, thus precluding the development of useful regression equations to predict washoff loads.

The quality of runoff from the simulated rainfall on the pasture was influenced by the disturbed perimeters of the plots; however, the runoff-to-rainfall ratios for the simulated storms fell within the range of ratios measured for natural storms over the adjacent 405-acre basin.

\section{INTRODUCTION}

From 1979 through 1982, the U.S. Geological Survey, in cooperation with the Denver Regional Council of Governments (DRCOG), participated in the Denver
Regional Urban Runoff Program as part of the Nationwide Urban Runoff Program (NURP) sponsored by the U.S. Environmental Protection Agency and the U.S. Geological Survey. The purposes of the nationwide program were to:

1. Collect data to establish a data base for typical urban drainage basins;

2. Determine the water-quality constituent loadings from these typical basins;

3. Develop methods of estimating loadings from ungaged basins; and

4. Test the effectiveness of various Best Management Practices (U.S. Geological Survey/U.S. Environmental Protection Agency Technical Coordination Plan on urban runoff studies, written commun., 1979).

The U.S. Geological Survey collected storm runoff data from seven small basins in the metropolitan Denver area while DRCOG collected storm runoff data and dry-weather flow data at four stations on the South Platte River and at one tributary in metropolitan Denver (Gibbs, 1981; Gibbs and Doerfer, 1982). Regression equations for urban runoff based on precipitation variables and drainage basin characteristics have been developed from these data (Ellis and others, 1984).

\section{PURPOSE}

As a special study in the Denver Regional Urban Runoff Program, the U.S. Geological Survey conducted simulated-rainfall runoff studies at two locations in metropolitan Denver, Colorado. The first location was a moderately used, paved street surface on the Denver Federal Center and the second was a pasture of native grass used for horse grazing at Rooney Ranch. 


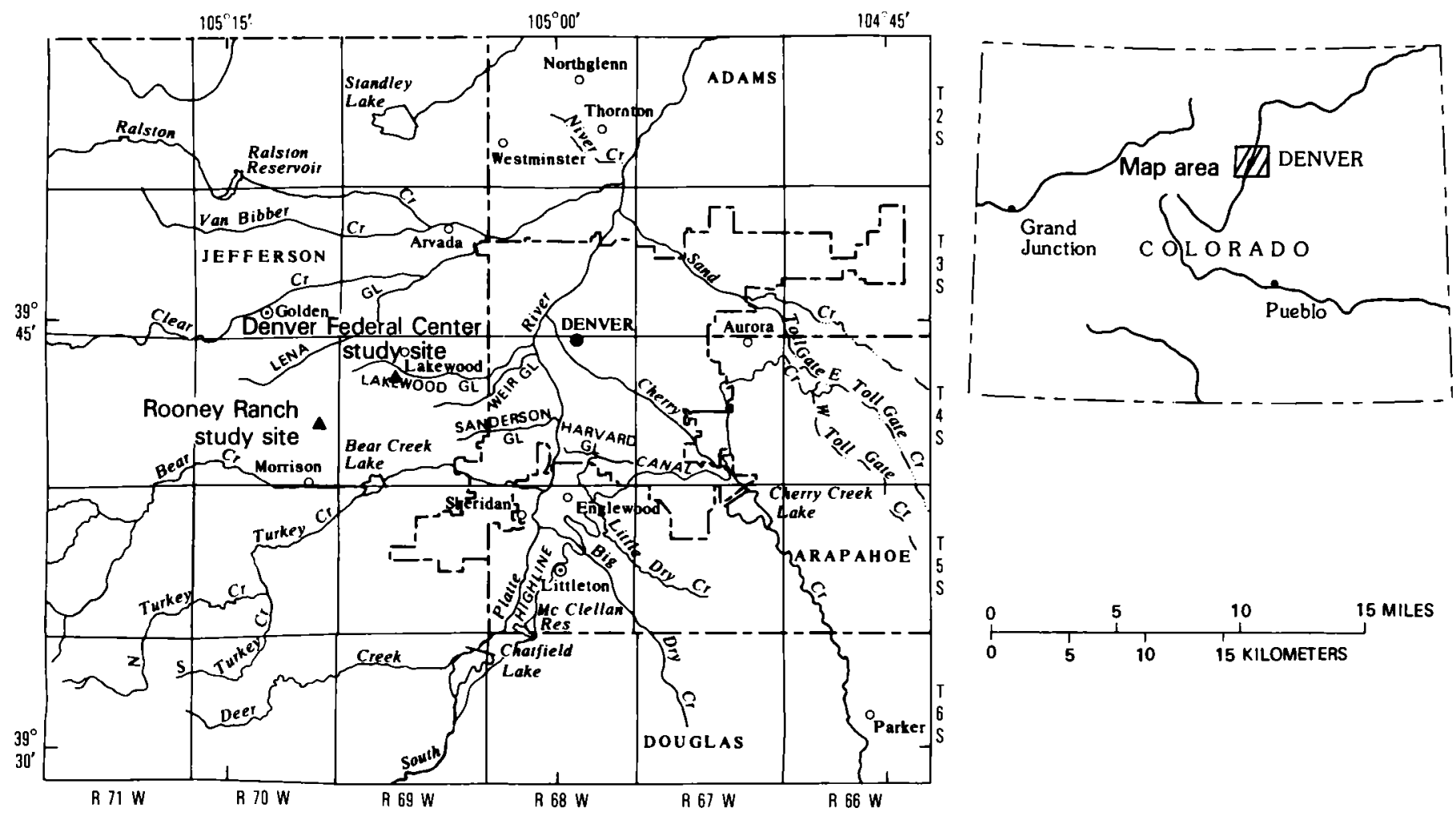

Figure 1.-Location of Denver Federal Center study site and Rooney Ranch study site.

The objectives of the study on the street surface were to:

1. Compare the runoff quantity and quality resulting from simulated rainfall intensities of approximately one-half inch per hour and two inches per hour;

2. Determine if a first flush of constituent loads was observed;

3. Compare the runoff characteristics from the street surface with those of an adjacent basin monitored for natural storm runoff over a period of 2 years;

4. Compare the runoff constituent loads to the constituent deposition; and

5. Perform statistical analysis of washoff constituent loads with several independent variables.

The objective of the study on the pasture was to compare runoff volumes and water-quality loads, normalized to area, and concentrations from the 400-square-foot plots with those from a 405-acre monitored basin. The runoff quantity and quality were compared to test the validity of data extrapolation from small basins.

\section{ACKNOWLEDGMENTS}

The Colorado Department of Highways supplied the traffic counter used in the Denver Federal Center study. The DRCOG conducted the vacuum sampling part of the Denver Federal Center study. William Jackson of the Special Studies Group, Colorado River Salinities Study, U.S. Bureau of Land Management, provided the equipment and assisted in the operation of the Rooney Ranch study. Gregg Lusby of the Public Lands Hydrology Program, Water Resources Division, U.S. Geological Survey, provided the equipment and personnel to conduct the Denver Federal Center rainfall simulations.

\section{STUDY AREA}

The study was conducted at two locations in the Denver metropolitan area, Colorado (fig. 1). The first location is the eastbound lane of North Avenue on the Denver Federal Center in Lakewood. The second location is Rooney Ranch, a pasture used for horse grazing about 4 miles southwest of the Denver Federal Center site. Both locations are on the edge of the plains next 
to the foothills of the Rocky Mountains. The climate is semiarid, and about 14 inches of precipitation fall in an average year.

These locations were chosen because of their proximity to larger basins studied in the NURP. Data for the rainfall simulation study on a street surface were collected at the Denver Federal Center. In addition, data on natural rainfall runoff from an adjacent 69-acre urban basin were collected during a 2-year period at station 06711635 North Avenue Storm Drain at Denver Federal Center as another part of the NURP.

Data for the rainfall simulation study on a native pasture were collected at two 400 -square-foot plots at Rooney Ranch. These rainfall simulation plots are approximately 1,000 feet downstream from a 405 -acre basin monitored for rainfall runoff during a 2-year period at station 06710610 Rooney Gulch at Rooney Ranch as another part of the NURP.

\section{DENVER FEDERAL CENTER SIMULATED-RAINFALL RUNOFF STUDY ON A STREET SURFACE}

\section{STUDY PLOTS}

North Avenue, a four-lane major access to the Denver Federal Center, was selected as the street site. A grassed, elevated median divides the two westbound and the two eastbound lanes. Except during extremely intense rainfall, rain falling on the median does not run off to the street. There is a concrete curb on the median side of the street and an asphalt curb on the other side. The asphalt surface of the street was in good condition, having been repaired prior to the study. The study plots were in the eastbound lanes which are 25-feet wide and slope downward 4.9 percent from west to east and 1.7 percent from north to south.

The street was divided into nine study plots of 25 feet by 40 feet with buffer zones of 50 to 60 feet between each plot to ensure that the simulated rainfall intended for one plot did not fall on another. The curbs provided boundaries on the north and south and other boundaries were created on the east and west ends using wooden boards backed with sand bags, covered with plastic sheets, and sealed with roofing sealant and duct tape. A 1-inch cut-throat flume was installed at the outfall of each plot. The slope of each plot is given below:

\begin{tabular}{lcc}
\hline Plot & \multicolumn{2}{c}{ Slope (percent) } \\
\cline { 2 - 3 } & North to South & West to East \\
\hline 1 & 1.6 & 3.6 \\
2 & 1.1 & 4.1 \\
3 & 1.4 & 5.2 \\
4 & 6.5 & 2.9 \\
5 & 2.4 & 5.4 \\
6 & 2.4 & 5.5 \\
7 & 2.4 & 5.4 \\
8 & 4.1 & 6.7 \\
9 & 2.1 & 5.4 \\
\hline
\end{tabular}

\section{DATA COLLECTION METHODS}

On June 1,1980 , the street used for this study was washed down by a fire hose and for the next 5 days simulated rainfall experiments were conducted on sections of the street using an assembly described by Lusby (1977). One storm of one-half inch per hour intensity and one storm of 2 inches per hour intensity were generated on each day for the 4 succeeding days and one rainfall simulation of one-half inch per hour intensity was conducted on the 5th day. Rainfall, runoff, and selected constituent deposition were measured. Samples of runoff were collected for water-quality analysis. Constituent deposition was measured by use of collection buckets and by vacuuming of the street by DRCOG personnel.

The 840-foot length of street was washed using highpressure fire hoses, 1 day prior to the first rainfall simulations, thus allowing approximately 1 day of constituent depositon. Starting at the lower end of the street, a rainfall storm was simulated on each plot and the resulting runoff was measured and sampled. The first simulation each day had an intensity of approximately one-half inch per hour and lasted about 1 hour. The second simulation was on the nearest plot, had an intensity of approximately 2 inches per hour, and lasted about one-half hour. There were five storms of about one-half inch per hour intensity and four storms of about 2 inches per hour intensity. There was no natural rainfall during the time of the study.

\section{SIMULATED RAINFALL}

Rainfall was simulated using equipment described by Lusby (1977). Water was supplied by a tank truck and supplemental storage bags through a feeder hose and supply lines connected to sprinklers set on 10-foot risers. The sprinklers were arranged in a grid to allow rain from adjacent sprinklers to overlap. The pressure 
at each sprinkler was regulated to approximately 28 pounds per square inch to provide uniform coverage at an intensity of about 2 inches per hour. The system was modified by deleting some sprinklers for the one-half inch per hour intensity storms. These intensities were target intensities-the actual intensities were somewhat different, primarily because the relative elevations of the sprinklers to the tank truck varied, and the feeder hoses leaked during the simulated rainfall on plots 5 and 7 . The leaking feeder hoses did not introduce any water onto the plots. The rainfall was momentarily halted and the leaks repaired. Hose supports made of reinforcing bars elevated the supply lines above the street surface to prevent overland-flow restrictions. Figure 2 illustrates the layout of the sprinklers.

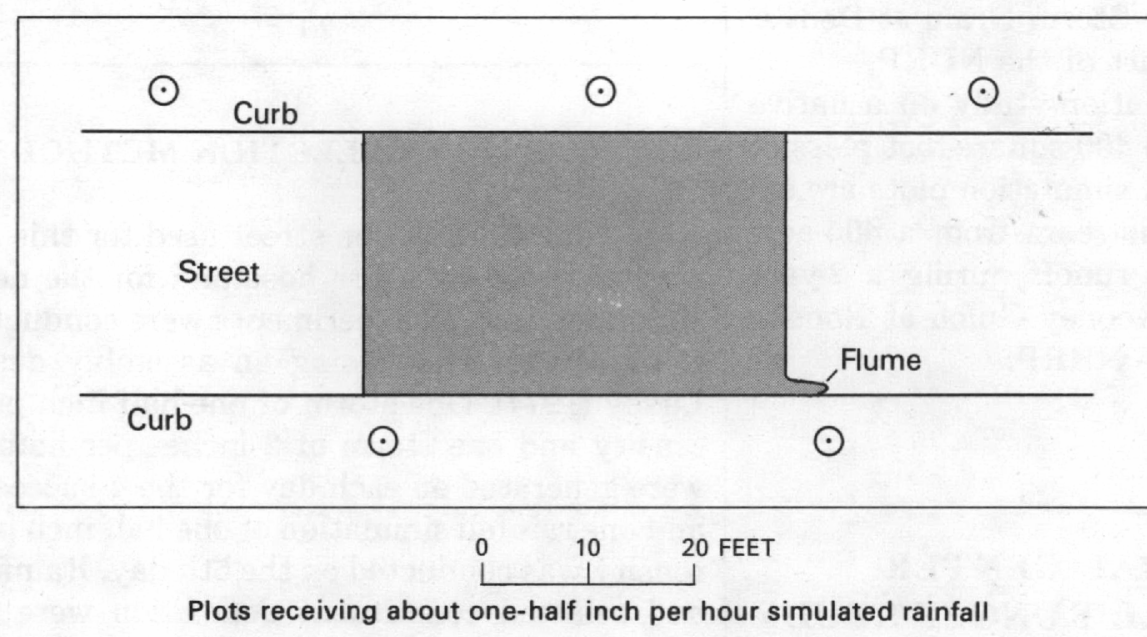

EXPLANATION

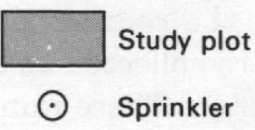

one-half inch per hour si

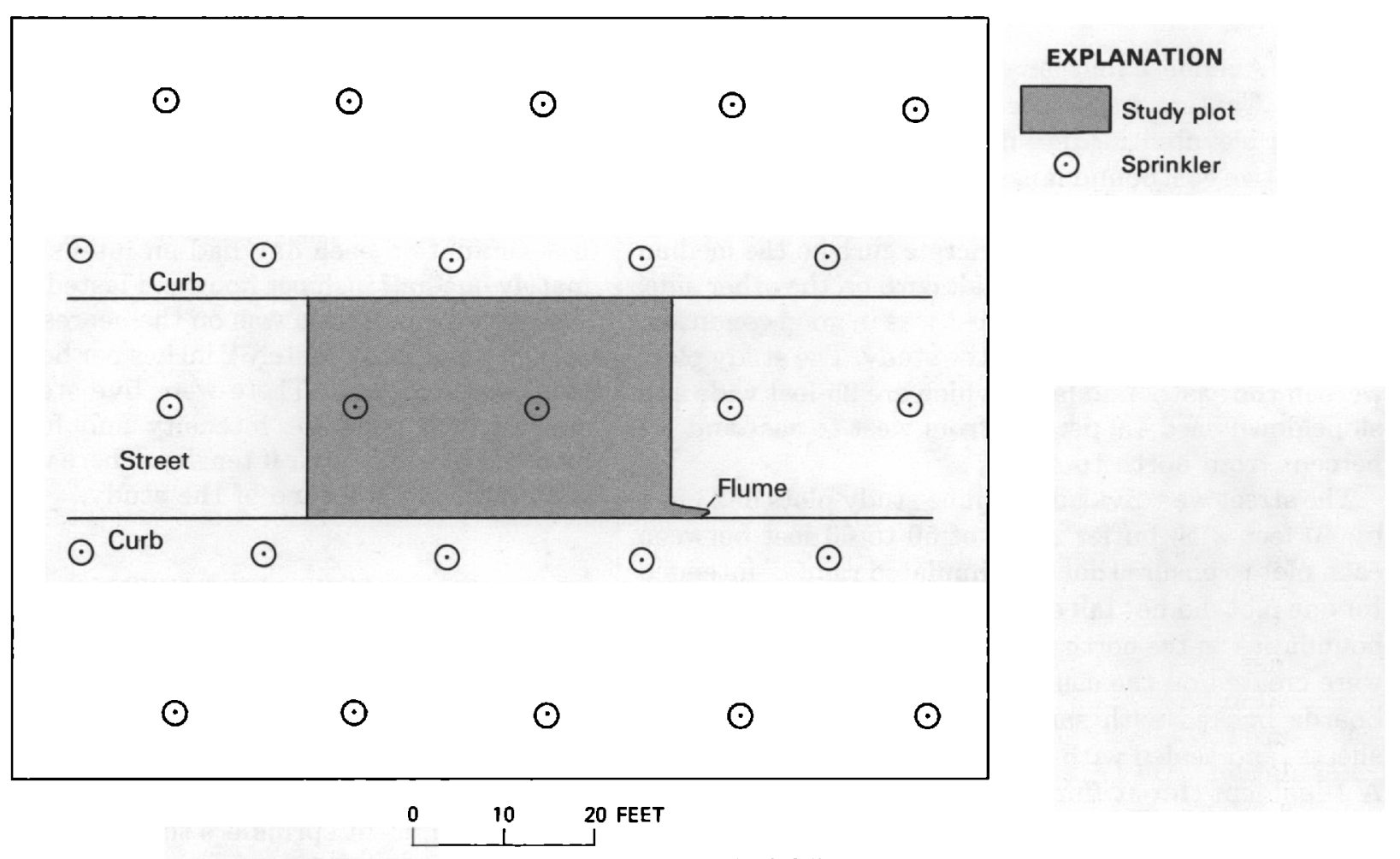

Plots receiving about 2 inches per hour simulated rainfall

Figure 2.-Denver Federal Center plots showing sprinkler and flume locations. 
The simulated rainfall was measured using five storage rain gages in each plot. The average rainfall on each plot was calculated using the Theissen polygon method (Linsley and Franzini, 1972).

\section{RUNOFF}

The flow was measured at the outfall of each plot using a 1-inch cut-throat flume (Holtan and others, 1962). The flume was rated at the study site using volumetric measurements. Discrete water-quality samples were collected by hand at the flume outflow and were analyzed for total suspended solids, total lead, total zinc, total manganese, total nitrogen, total phosphorus, and total organic carbon. The analyses were performed by the U.S. Geological Survey Denver Central Laboratory according to "Techniques of WaterResources Investigations of the United States Geological Survey" (U.S. Geological Survey, 1979). The total recoverable method was used for trace element analyses, and the total phase method was used for all other constituents.

\section{CONSTITUENT DEPOSITION}

Constituent deposition was determined daily by the amount of constituent accumulation in plastic buckets which had been scrubbed, rinsed with distilled water, and then placed either along the street or approximately 300 feet from the street in an open space. Twenty clean buckets were placed during the day of street washing. On each day of rainfall simulation, two buckets from along the street were collected, their contents combined, and the contents analyzed by the U.S. Geological Survey Denver Central Laboratory. The constituents selected for analysis and the analytical methods used were the same as those for the runoff. The contents of the buckets in the open space were treated similarly.

Deposition of constituents was also determined by measuring the amounts of constituents vacuumed from the street surface each day by DRCOG personnel. Each day, for the 5-day period of rainfall simulations, a measured area of the street surface adjacent to the area selected for study was vacuumed and the contents of the vacuum cleaner sent to the Soils Testing Laboratory, Colorado State University at Fort Collins, Colo. for chemical analysis. The method of analysis for trace elements, unfortunately, did not correspond to the method used for the water samples analyzed in this study. The plant-available method (Lindsay and Norvell, 1978), a mild digestion, was used for the vacuumed samples. To compare the data from the vacuumed samples with all other trace-element data in this study, replicates of five vacuumed samples of street deposition were analyzed by both methods and average adjustment factors determined. Adjustment factors of 2.1 for lead, 5.9 for zinc, and 11 for manganese were developed from the replicate data. The plant-available method results were multiplied by these adjustment factors for comparability. Analytical methods for total nitrogen, total phosphorus, and total suspended solids were consistent with analysis methods for all other samples collected in the study. The Soils Testing Laboratory was unable to analyze for total organic carbon.

\section{RELATED MEASUREMENTS}

The temperatures of the street surface, runoff, and air were measured for each simulated storm. The street and air temperatures were measured before the simulated rainfall began. The runoff temperature was measured near the end of the runoff period. The data collected during this experiment are given below and may be used by other personnel for different applications.

\begin{tabular}{lccc}
\hline Plot & Street & $\begin{array}{c}\text { Temperature, in degrees Celsius } \\
\text { Runoff }\end{array}$ & Air \\
\hline 1 & 17.0 & 24.0 & 16.0 \\
2 & 26.5 & 25.0 & 23.5 \\
3 & 23.5 & 27.5 & 23.5 \\
4 & 25.5 & 24.0 & 25.5 \\
5 & 26.0 & 29.5 & 23.5 \\
6 & 33.5 & 30.5 & 28.0 \\
7 & 29.0 & 29.0 & 26.5 \\
8 & 28.0 & 23.0 & 29.0 \\
9 & 27.0 & 32.0 & 27.0 \\
\hline
\end{tabular}

Vehicular traffic between the time of street washing and each rainfall simulation was measured by a traffic counter. The street was open to incoming rush-hour traffic each morning. The eastbound lanes were then closed to traffic only for the duration of the two experiments. The street was reopened by lunchtime. The traffic data are given below:

\begin{tabular}{lc}
\hline Plot & Traffic oince streot washing, in number of vebicles \\
\hline 1,2 & 943 \\
3,4 & 2,518 \\
5,6 & 4,366 \\
7,8 & 6,327 \\
9 & 7,990 \\
\hline
\end{tabular}



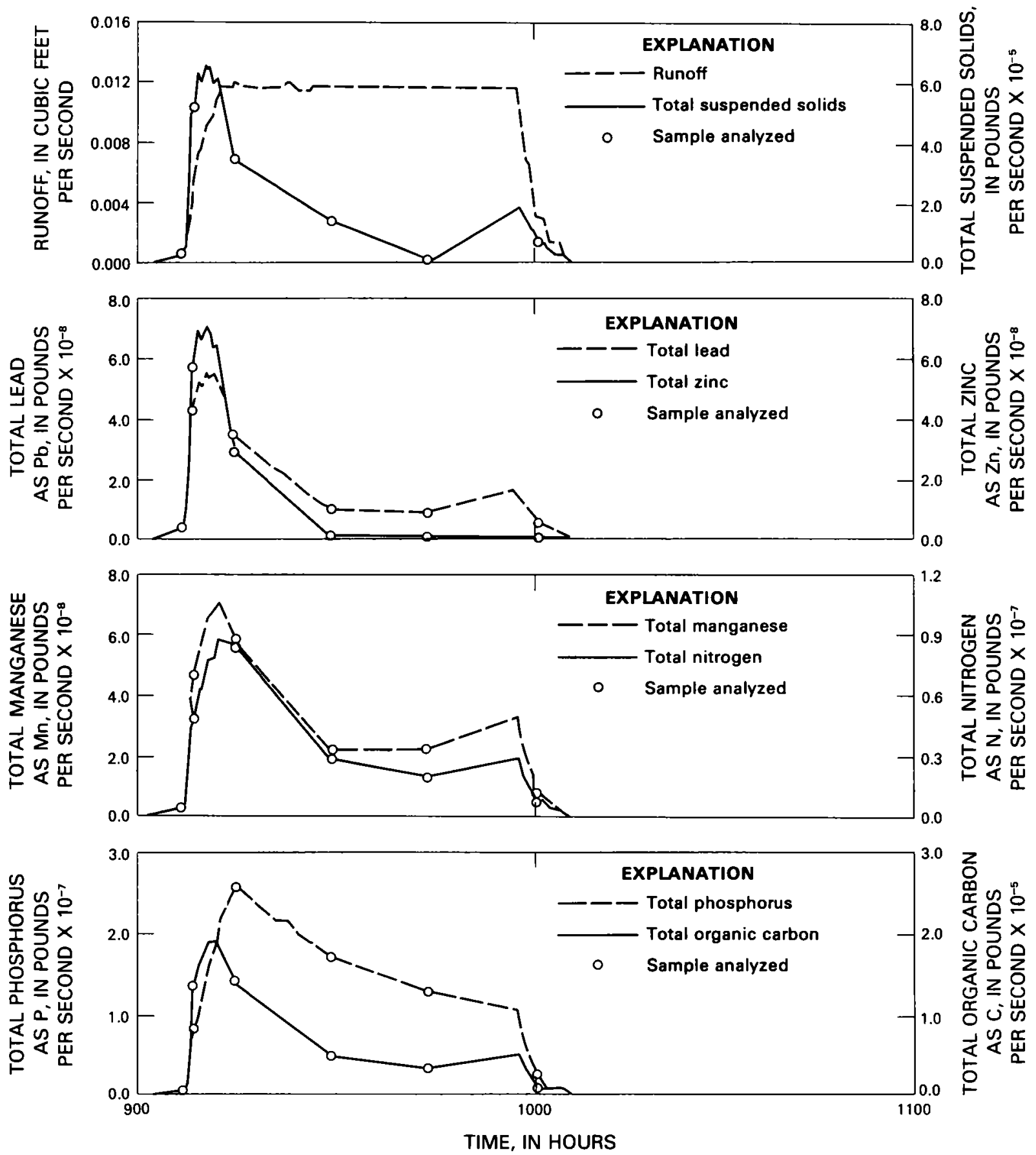

Figure 3.-Runoff and washoff loads of selected water-quality constituents for Denver Federal Center plot 1, June 2, 1980.

\section{RUNOFF QUANTITY}

The characteristics of the simulated rainfall and the resulting runoff are presented in table 1 . The runoff hydrograph for each plot is shown in figures $3-11$. The average runoff-to-rainfall ratio was $\mathbf{0 . 8 2}$ for the lower rainfall intensity storms and 0.98 for the higher rainfall intensity storms. The difference between the ratios may be partly due to: (1) More evaporation of the water from the street during the lower intensity rainfall than during the higher intensity rainfall, and (2) the impervious retention being a higher percentage of the rainfall during the lower intensity storms.

Another factor contributing to the difference between the two runoff-rainfall ratios may be the inaccuracy of flow measurements. The peak flows for each site 

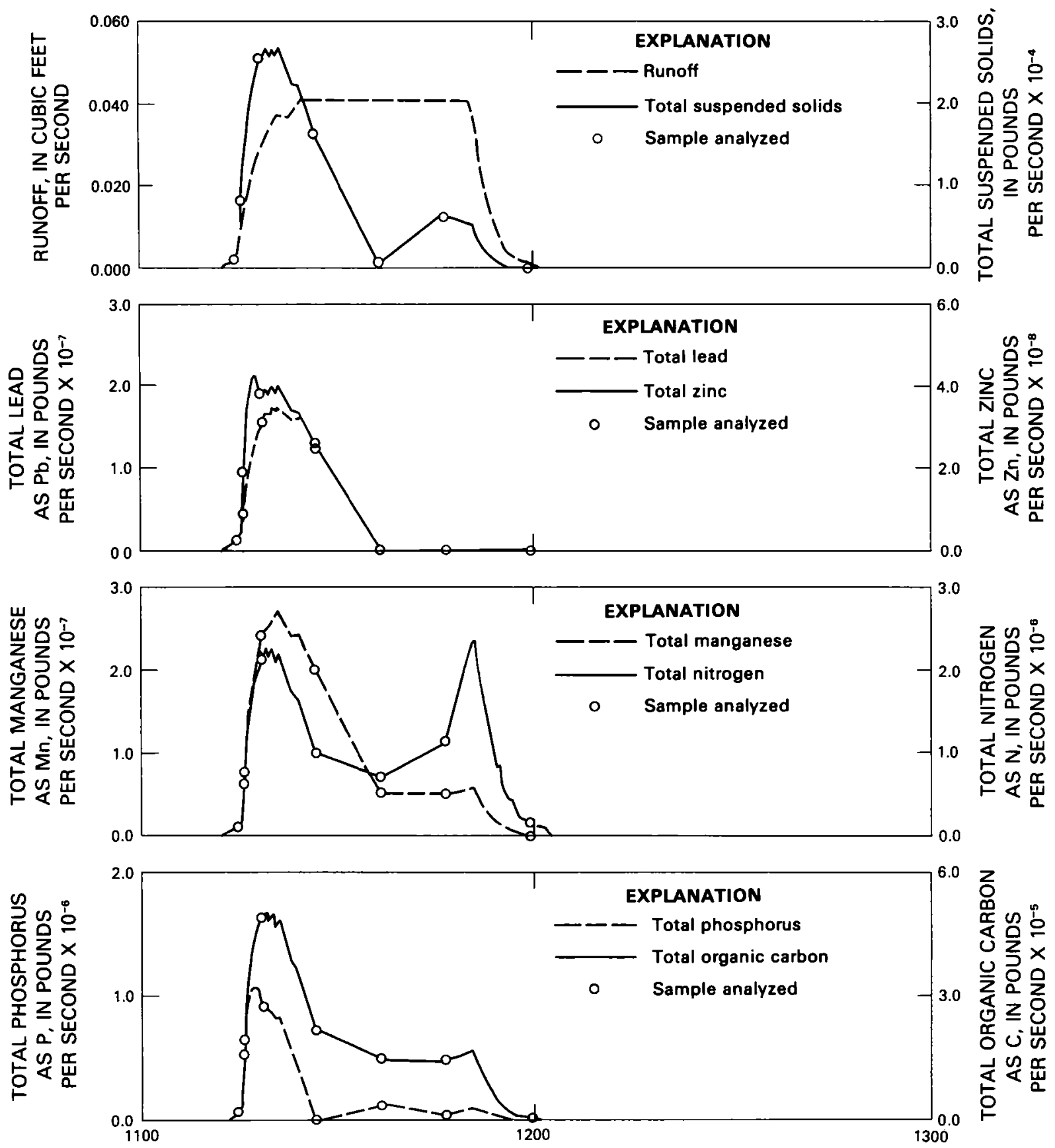

TIME, IN HOURS

FigURE 4.-Runoff and washoff loads of selected water-quality constituents for Denver Federal Center plot 2, June 2, 1980.

were predicted using the rational method (Linsley and Franzini, 1972) which states that the runoff rate from impervious surfaces will approach the rate of rainfall if the rainfall rate is constant. The measured peak flows were generally less than the predicted peak flows. Analysis of the peak-flow data shown in table 1 suggests that the rating of the cut-throat flume may have been low for the range of stage measured during the one-half inch per hour intensity storm.

Two methods were used to determine the impervious retention at each site. The first method was to calculate the quantity of simulated rainfall normalized to area that fell before runoff began. The second method was to calculate: (a) The quantity of rainfall that fell before the runoff reached steady-state flow condition, (b) the 

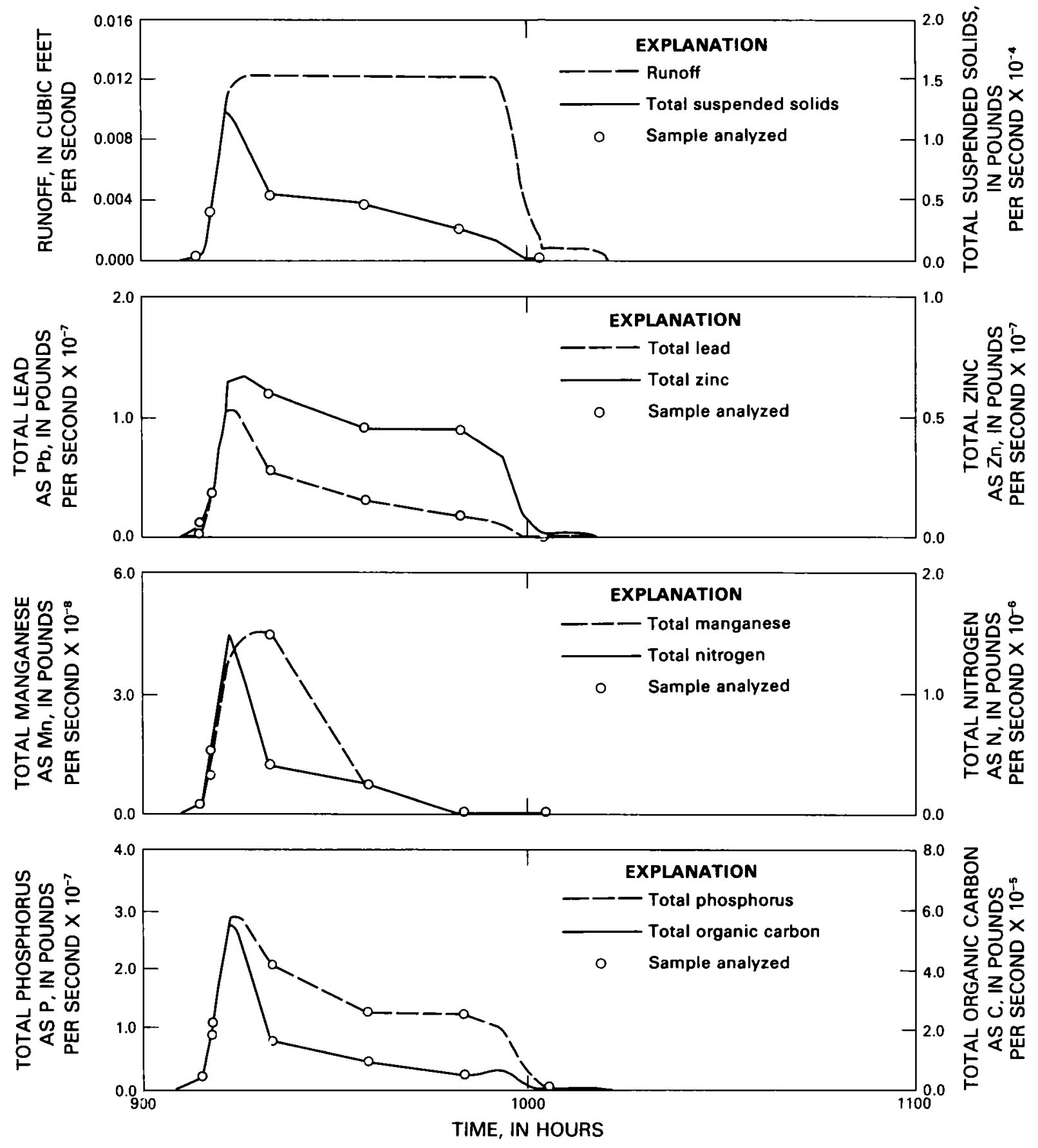

FigURE 5.-Runoff and washoff loads of selected water-quality constituents for Denver Federal Center plot 3, June 3, 1980.

volume of runoff before steady-state conditions were reached, and (c) the volume of runoff after rainfall ceased. The impervious retention calculated by this method is the difference between the quantity of rainfall and the sum of the volumes of runoff, all normalized to area. The results of these two methods and their averages are presented in table 1 . The average impervious retention for all nine plots was about 0.05 inch. This value of impervious retention is fairly consistent with the values of impervious retention determined for a larger urban basin in the area (Ellis and others, 1984). 

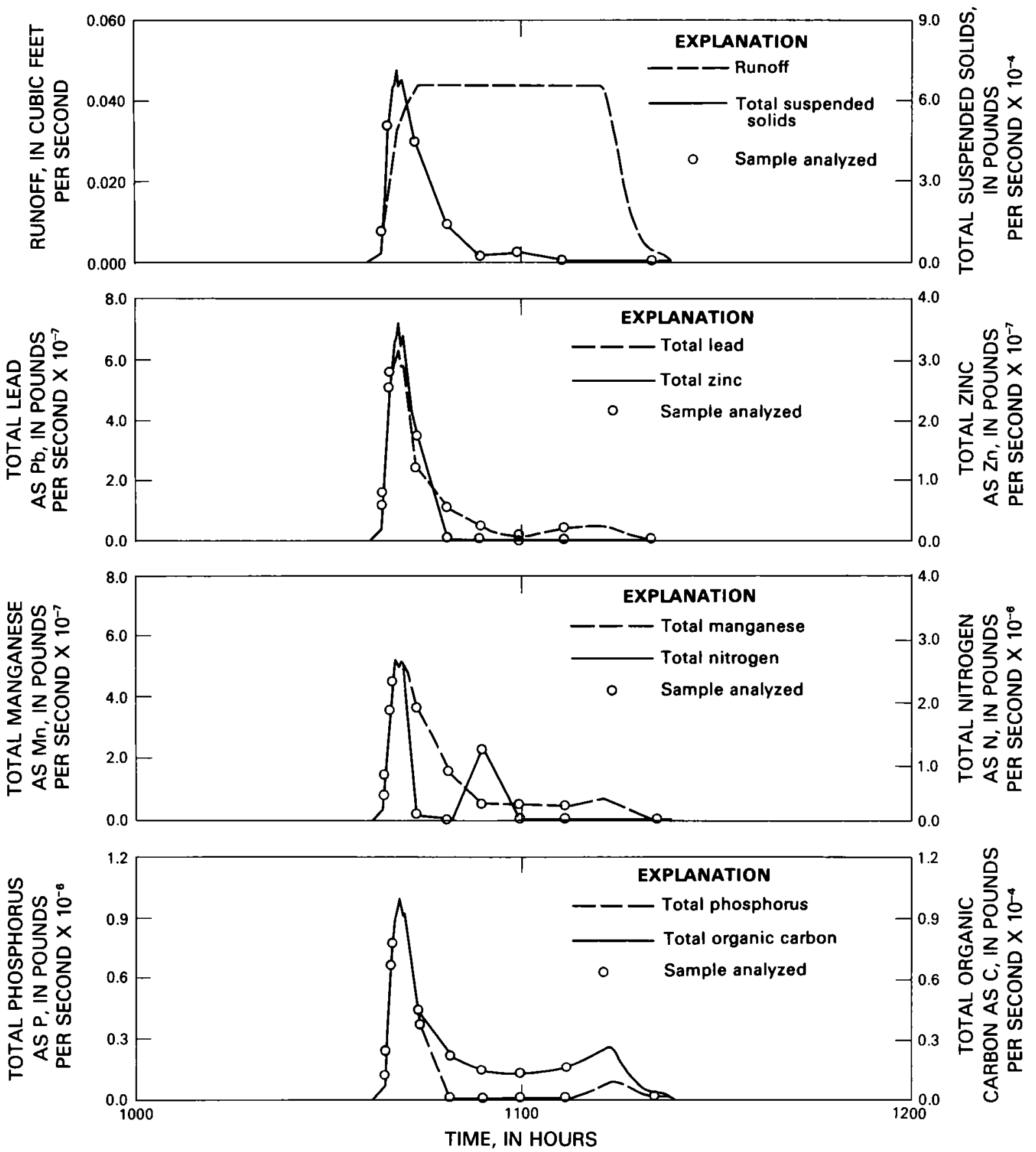

FIGURE 6.-Runoff and washoff loads of selected water-quality constituents for Denver Federal Center plot 4, June 3, 1980.

\section{RUNOFF QUALITY}

Samples for water-quality analysis were collected during the rainfall simulation at varied frequencies to provide data to calculate the washoff loads of selected constituents in the runoff from the nine plots. Trace elements were analyzed using the total recoverable method and are referred to hereafter as total trace elements. Runoff-sample collection times are indicated on the hydrographs in figures 3-11. In addition, composite samples of applied water collected from sprinklers during various stages of each rainfall simulation were 

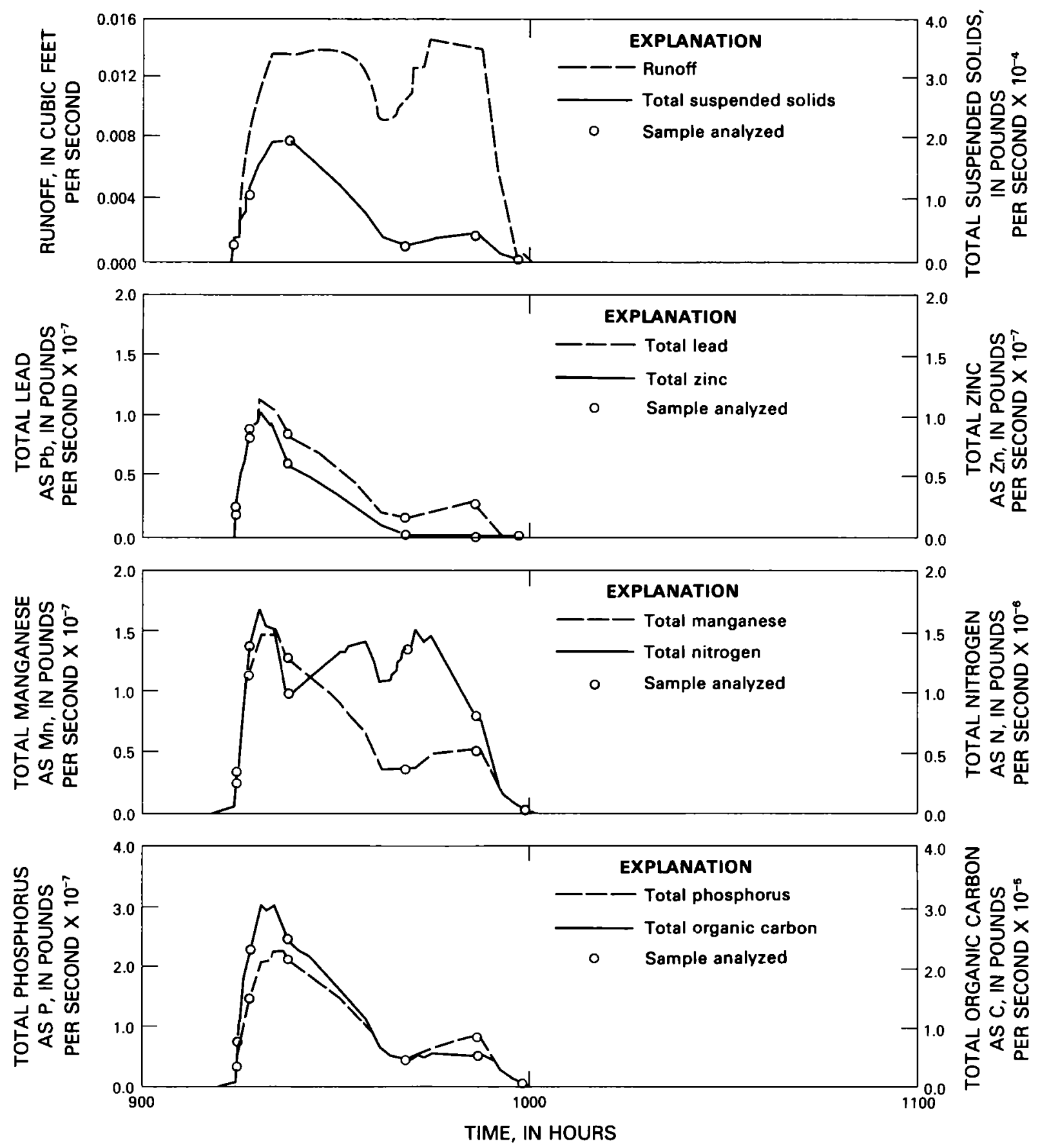

FigurE 7.-Runoff and washoff loads of selected water-quality constituents for Denver Federal Center plot 5, June 4, 1980.

analyzed for the selected constituents. The constituent concentrations in the applied water samples were subtracted from the concentrations in the runoff samples. Washoff loads were computed using this difference and the flow rate. The washoff loads for each plot and the mean washoff loads are presented in table 2. Graphs of the washoff loads are shown in figures 3-11.

The graphs of washoff loads from plot 6, figure 8, show a double peak in washoff loads, whereas the 

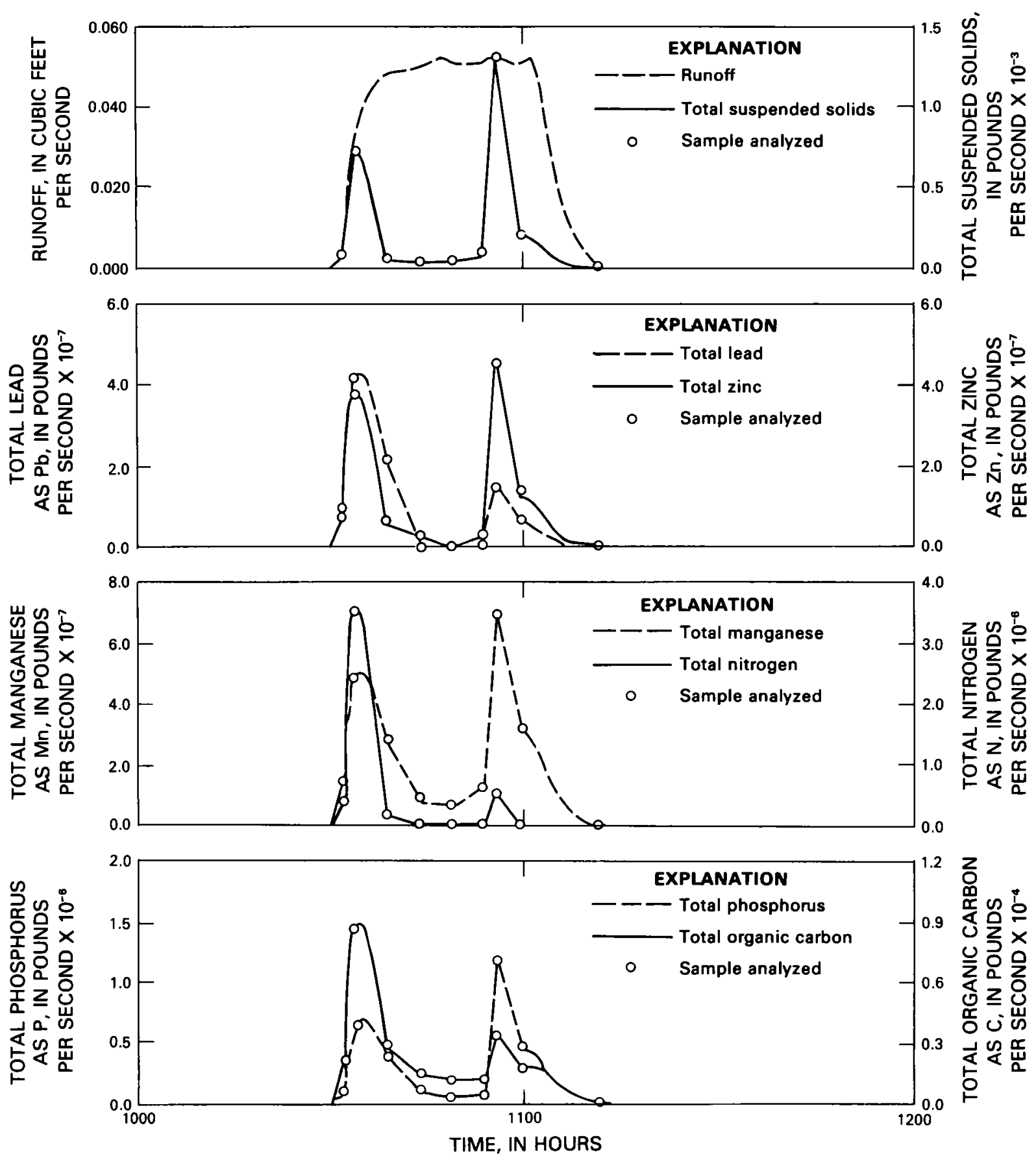

FIGURE 8.-Runoff and washoff loads of selected water-quality constituents for Denver Federal Center plot 6, June 4, 1980.

graphs of washoff loads from the other plots have a single peak in washoff loads. The flume used to measure the runoff from plot 6 was slightly misaligned, resulting in a backwater effect and a small pond upgradient of the fume, where deposition was observed.
The small pond was agitated toward the end of the simulation, and the deposited materials were transported through the weir, where samples were collected. The double peak of washoff loads depicted in figure 8 is not indicative of the washoff mechanisms from 

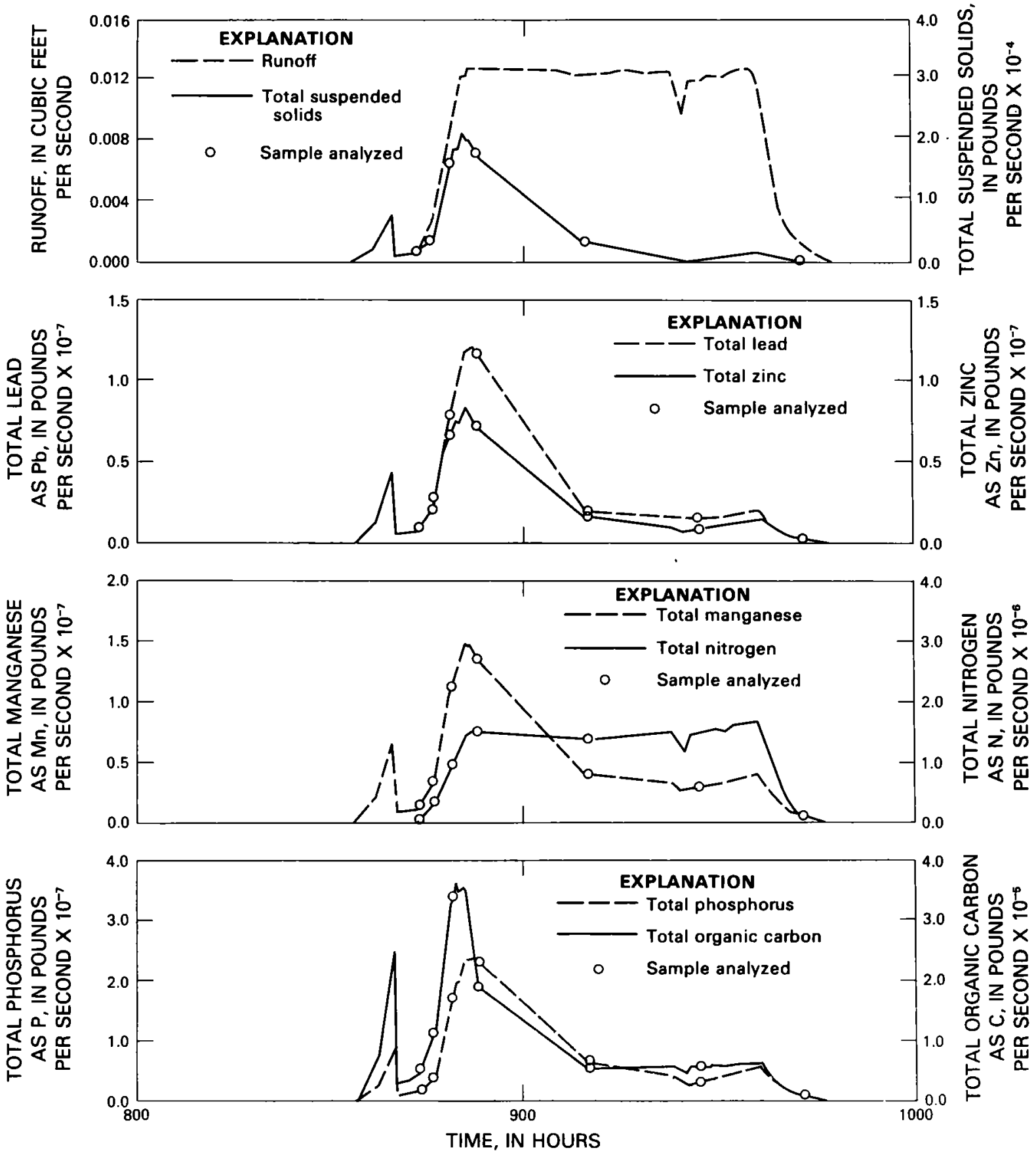

FIGURE 9.-Runoff and washoff loads of selected water-quality constituents for Denver Federal Center plot 7, June 5, 1980.

the plots but resulted from deposition and agitation of the washoff loads.

The concentration of total nitrogen in the runoff samples was not sufficiently higher than the concentration in the applied water for the difference to offset analytical errors. Therefore, the results presented for concentrations and loads of total nitrogen may be in error by an order of magnitude or less. The possible error in the concentrations and loads of total nitrogen must be considered when these data are used in any 
SIMULATED RAINFALL ON A STREET SURFACE
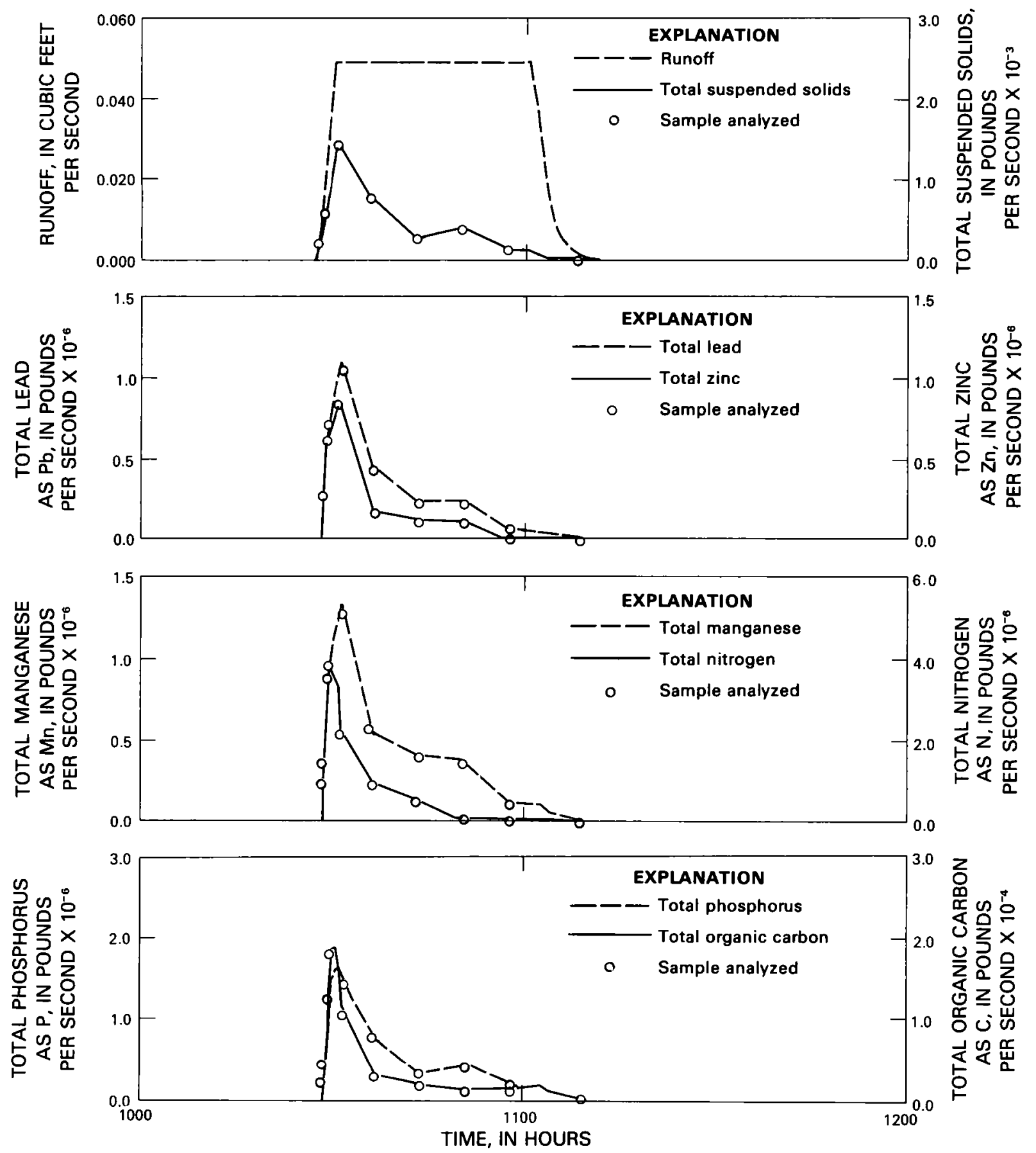

FIGURE 10.-Runoff and washoff loads of selected water-quality constituents for Denver Federal Center plot 8, June 5, 1980.

interpretation. In particular, the use of these data for statistical analysis could result in erroneous conclusions.

A first flush of most of the constituent loads studied took place in the runoff from the simulated rainfall. A first flush of constituent load occurs when the first 25 percent of the runoff volume contains 50 percent or more of the constituent load. Data from larger urban basins in the metropolitan Denver area indicate that a first flush of loads is not common in basins of 33 to 167 acres. This suggests that relatively small areas of impervious area may have a first flush of load, but due 

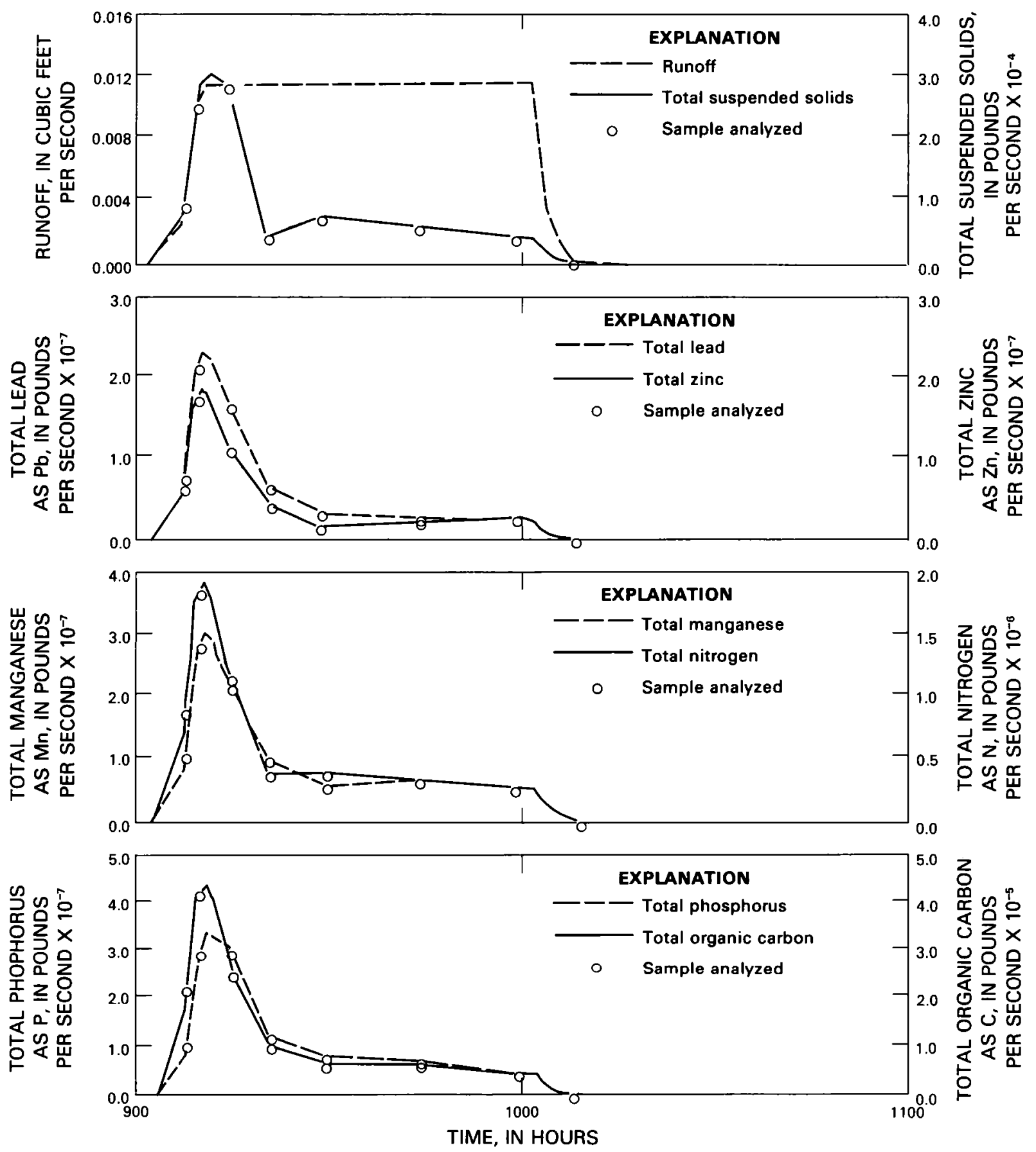

FIGURE 11.-Runoff and washoff loads of selected water-quality constituents for Denver Federal Center plot 9, June 6, 1980.

acres. This suggests that relatively small areas of impervious area may have a first flush of load, but due to timing of runoff from various sections of the basin the resultant basin loads are attenuated. That is, each small runoff event may progressively move the available constituents toward the basin outlet. The distribution of available constituents throughout a basin prior to a runoff event may also be a determining factor in the distribution of the constituent load throughout the runoff period.

The washoff loads versus number of days since street washing are presented in figures 12-18 for the two 
SIMULATED RAINFALL ON A STREET SURFACE

TABLE 1.-Characteristics of simulated rainfall on the Denver Federal Center plots, resulting runoff, and impervious retention

\begin{tabular}{|c|c|c|c|c|c|c|c|c|c|c|}
\hline \multirow[b]{2}{*}{ Plot } & \multirow[b]{2}{*}{$\begin{array}{l}\text { Rainfall } \\
\text { (inches) }\end{array}$} & \multirow[b]{2}{*}{$\begin{array}{l}\text { Reinfall } \\
\text { duration } \\
\text { (hours) }\end{array}$} & \multirow{2}{*}{$\begin{array}{l}\text { Rainfall } \\
\text { intensity } \\
\text { (inches } \\
\text { per hour) }\end{array}$} & \multirow[b]{2}{*}{$\begin{array}{l}\text { Runoff } \\
\text { (inches) }\end{array}$} & \multirow[b]{2}{*}{$\begin{array}{l}\text { Runoff-to- } \\
\text { rainfall } \\
\text { ratio }\end{array}$} & \multirow{2}{*}{$\begin{array}{l}\text { Measured } \\
\text { pealk flow } \\
\text { (cubic feet } \\
\text { per second) }\end{array}$} & \multirow{2}{*}{$\begin{array}{l}\text { Peak flow } \\
\text { predicted by } \\
\text { rational method } \\
\text { (cubic feet } \\
\text { per second) }\end{array}$} & \multicolumn{3}{|c|}{ Imparvious retention ${ }^{1}$} \\
\hline & & & & & & & & $\begin{array}{c}\text { Method } \\
1 \\
\text { (inches) }\end{array}$ & $\begin{array}{l}\text { Method } \\
2 \\
\text { (inches) }\end{array}$ & $\begin{array}{l}\text { Averege } \\
\text { (inches) }\end{array}$ \\
\hline $1 \ldots \ldots$ & 0.53 & 0.95 & 0.56 & 0.43 & 0.81 & 0.012 & 0.013 & 0.046 & 0.048 & 0.047 \\
\hline $2 \ldots \ldots$ & 1.08 & .60 & 1.80 & 1.05 & .97 & .041 & .042 & .073 & .064 & .068 \\
\hline 3 & .53 & .85 & .62 & .43 & .81 & .012 & .014 & .043 & .028 & .036 \\
\hline 4 & 1.17 & .59 & 1.98 & 1.13 & .97 & .044 & .046 & .058 & .011 & .034 \\
\hline $7 \ldots$ & .59 & .93 & .63 & .46 & .78 & .013 & .015 & .037 & -- & -- \\
\hline 8 & 1.25 & .57 & 2.19 & 1.22 & .98 & .050 & .051 & .061 & .022 & .042 \\
\hline$\ldots$ & .55 & .98 & .56 & .46 & .84 & .011 & .013 & .044 & .046 & .045 \\
\hline
\end{tabular}

${ }^{1}$ See page 7 for explanation of methods used to determine impervious retention.

TABLE 2.-Washoff and mean washoff loads of selected water-quality constituents from plots 1-9 at the Denver Federal Center [Except for intensity of rainfall, all units are in pounds per acre]

\begin{tabular}{|c|c|c|c|c|c|c|c|c|c|c|}
\hline \multirow{2}{*}{\multicolumn{2}{|c|}{ Plot }} & \multirow{2}{*}{$\begin{array}{l}\text { Intensity } \\
\text { of } \\
\text { rainfall } \\
\text { (inches per } \\
\text { hour) }\end{array}$} & \multirow{2}{*}{$\begin{array}{c}\text { Days } \\
\text { since } \\
\text { street } \\
\text { washing }\end{array}$} & \multicolumn{7}{|c|}{ Total } \\
\hline & & & & $\begin{array}{l}\text { suspended } \\
\text { solids }\end{array}$ & load & zinc & manganese & nitrogen & phosphorus & $\begin{array}{l}\text { organic } \\
\text { carbon }\end{array}$ \\
\hline $\begin{array}{l}1 \\
2 \\
3\end{array}$ & $\begin{array}{l}\ldots \\
\ldots \\
\ldots\end{array}$ & $\begin{array}{r}0.56 \\
1.80 \\
.62\end{array}$ & $\begin{array}{l}1 \\
1 \\
2\end{array}$ & $\begin{array}{c}2.6 \\
11 \\
6.4\end{array}$ & $\begin{array}{r}0.0026 \\
.0060 \\
.0051\end{array}$ & $\begin{array}{r}0.0016 \\
.0014 \\
.0063\end{array}$ & $\begin{array}{c}0.0047 \\
.012 \\
.0022\end{array}$ & $\begin{array}{c}0.055 \\
.14 \\
.046\end{array}$ & $\begin{array}{r}0.022 \\
.026 \\
.021\end{array}$ & $\begin{array}{l}1.0 \\
2.3 \\
2.0\end{array}$ \\
\hline $\begin{array}{l}4 \\
5 \\
6\end{array}$ & $\begin{array}{l}\cdots \\
\cdots \\
\cdots\end{array}$ & $\begin{array}{r}1.98 \\
.64 \\
2.30\end{array}$ & $\begin{array}{l}2 \\
3 \\
3\end{array}$ & $\begin{array}{c}13 \\
8.6 \\
25\end{array}$ & $\begin{array}{l}.011 \\
.0049 \\
.0099\end{array}$ & $\begin{array}{l}.0047 \\
.0030 \\
.012\end{array}$ & $\begin{array}{l}.014 \\
.0081 \\
.024\end{array}$ & $\begin{array}{l}.041 \\
.13 \\
.052\end{array}$ & $\begin{array}{l}.014 \\
.012 \\
.034\end{array}$ & $\begin{array}{l}2.7 \\
1.4 \\
2.6\end{array}$ \\
\hline $\begin{array}{l}7 \\
8 \\
9\end{array}$ & $\begin{array}{l}\cdots \\
\cdots \\
\cdots\end{array}$ & $\begin{array}{r}.63 \\
2.19 \\
.56\end{array}$ & $\begin{array}{l}4 \\
4 \\
5\end{array}$ & $\begin{array}{l}8.9 \\
42 \\
14\end{array}$ & $\begin{array}{l}.0063 \\
.031 \\
.0091\end{array}$ & $\begin{array}{l}.0044 \\
.018 \\
.0068\end{array}$ & $\begin{array}{l}.0091 \\
.043 \\
.014\end{array}$ & $\begin{array}{l}.20 \\
.064 \\
.082\end{array}$ & $\begin{array}{l}.014 \\
.049 \\
.017\end{array}$ & $\begin{array}{l}1.7 \\
3.3 \\
1.7\end{array}$ \\
\hline \multicolumn{4}{|c|}{ Mean } & 15 & .0095 & .0065 & .015 & .090 & .023 & 2.1 \\
\hline
\end{tabular}

TABLE 3.-Event mean concentrations of selected water-quality constituents in the runoff from plots 1-9 at the Denver Federal Center and concentrations in the applied water

[mg/L = milligrams per liter; $\mu g / \mathrm{L}=$ micrograms per liter; concentrations in the applied water are shown in parentheses and are not included in the event mean concentrations]

\begin{tabular}{|c|c|c|c|c|c|c|c|c|c|}
\hline Plot & $\begin{array}{c}\text { Intensity } \\
\text { of } \\
\text { rainfall } \\
\text { (inches } \\
\text { per hour) }\end{array}$ & $\begin{array}{c}\text { Days } \\
\text { since } \\
\text { street } \\
\text { washing }\end{array}$ & \multicolumn{7}{|c|}{ Total } \\
\hline $1 \ldots$ & 0.56 & 1 & $27(18)$ & $27(4)$ & $17(50)$ & $49(20)$ & $0.57(1.2)$ & $0.23(0.15)$ & $10(4.4)$ \\
\hline 2 & 1.80 & 1 & $45(12)$ & $25(14)$ & $5.8(90)$ & $52(10)$ & $.58(1.1)$ & $.11(.10)$ & $9.8(3.3)$ \\
\hline $3 \ldots$ & .62 & 2 & $66(7)$ & $53(9)$ & $66 \quad(80)$ & $22(70)$ & $.47(1.7)$ & $.22(.01)$ & 20 \\
\hline $6 \ldots$ & 2.30 & 3 & $92(24)$ & $37(36)$ & $46(60)$ & $91(10)$ & $.19(1.2)$ & $.13(.02)$ & 9.9(3.7) \\
\hline 7 & .63 & 4 & $85(29)$ & $60(3)$ & $42(30)$ & $87(10)$ & $1.9(2.1)$ & $.13(.01)$ & $16(3.4)$ \\
\hline $8 \ldots$ & 2.19 & 4 & $150(20)$ & $110(4)$ & $66 \quad(60)$ & $160(10)$ & $.23(2.9)$ & $.18(.02)$ & $12(3.8)$ \\
\hline $9 \ldots$ & .56 & 5 & $130(21)$ & $88(0)$ & $66(40)$ & $140(20)$ & $.80(.95)$ & $.16(.01)$ & $17(4.0)$ \\
\hline
\end{tabular}




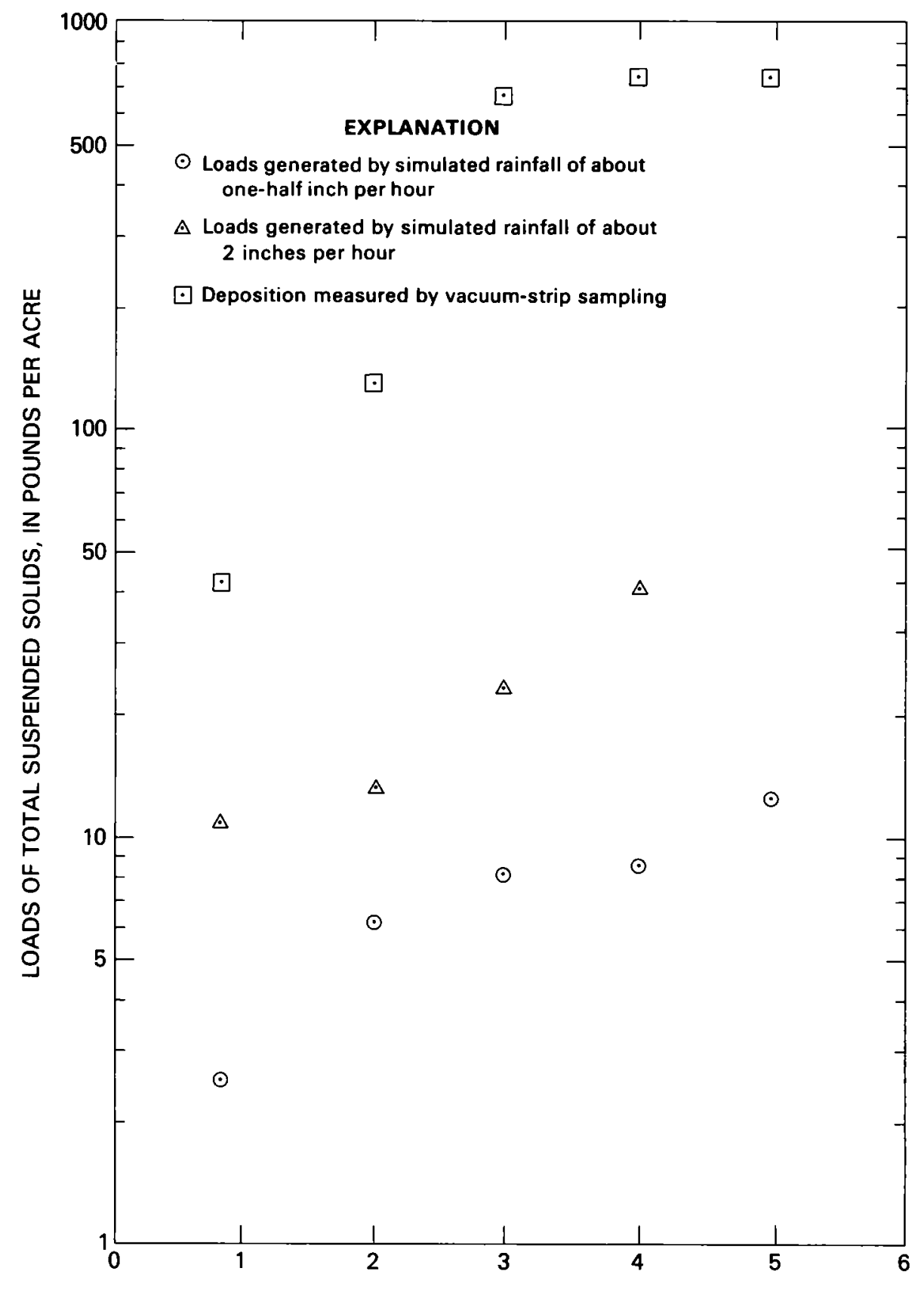

DAYS SINCE STREET WASHING

FIGURE 12.-Total suspended solids washoff loads and deposition measured by vacuum-strip sampling versus number of days since street washing for the Denver Federal Center plots, June 2-6, 1980.

rainfall intensities. Also indicated are the deposition loads of each constituent measured by vacuum-strip sampling. The loads produced from the higher intensity rainfall generally increase with the number of days since street washing. The loads produced by the lower intensity rainfall show an inconsistent pattern. This suggests that antecedent dry days may be a more important factor in determining loads from higher intensity rainfall-runoff events than from lower intensity events. Another possible explanation is that the variability and 


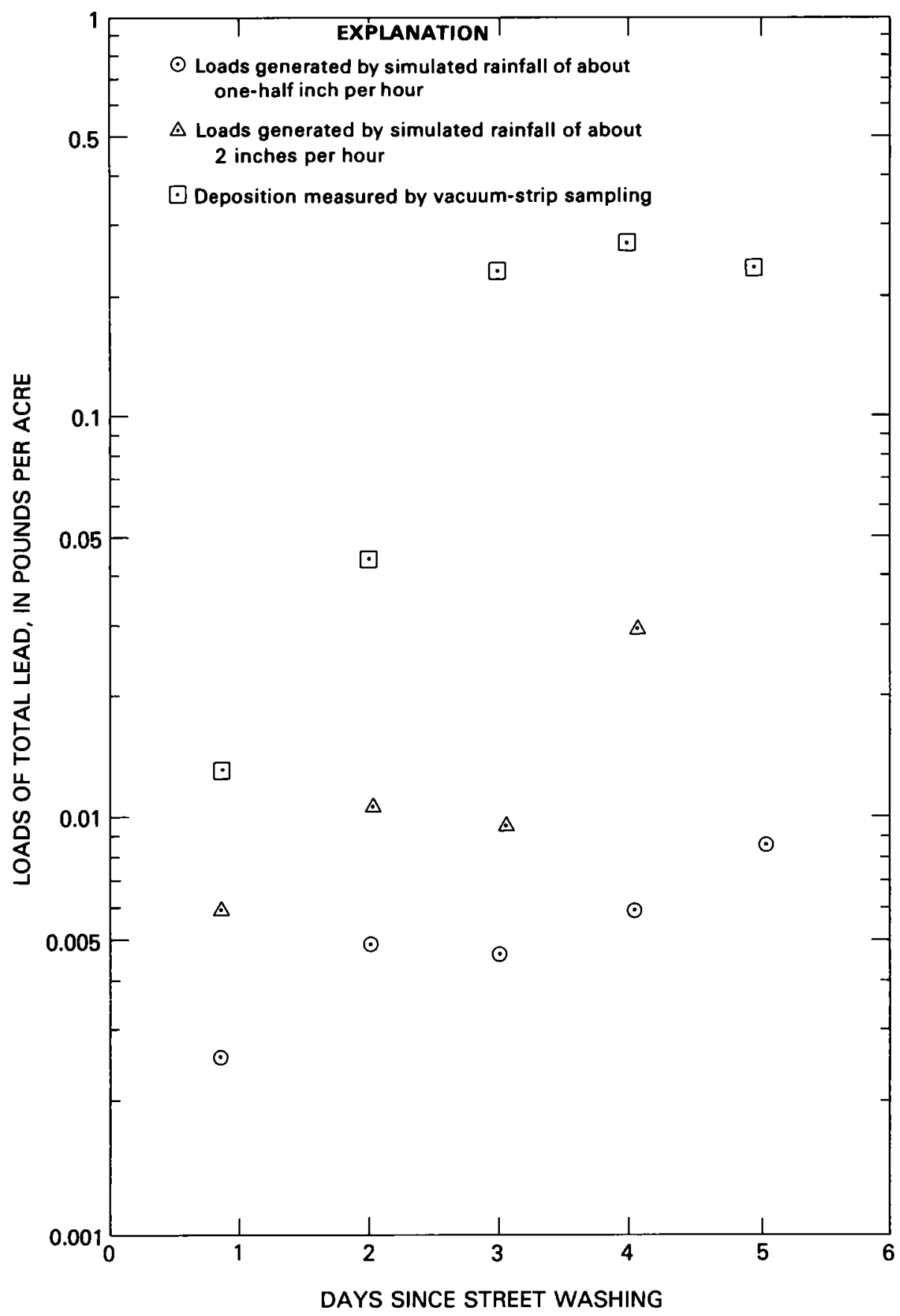

Figure 13.-Total lead washoff loads and deposition measured by vacuum-strip sampling versus number of days since street washing for the Denver Federal Center plots, June 2-6, 1980.

error of the measurement are a larger percent of the value for the loads from lower intensity storms.

The event mean concentrations of the selected constituents in the runoff are presented in table 3 . The event mean concentrations of total suspended solids, total lead, total zinc, and total manganese generally increased with the number of days since street washing. The event mean concentrations of total phosphorus and total organic carbon remained fairly constant with the increase in the number of days since street washing. 


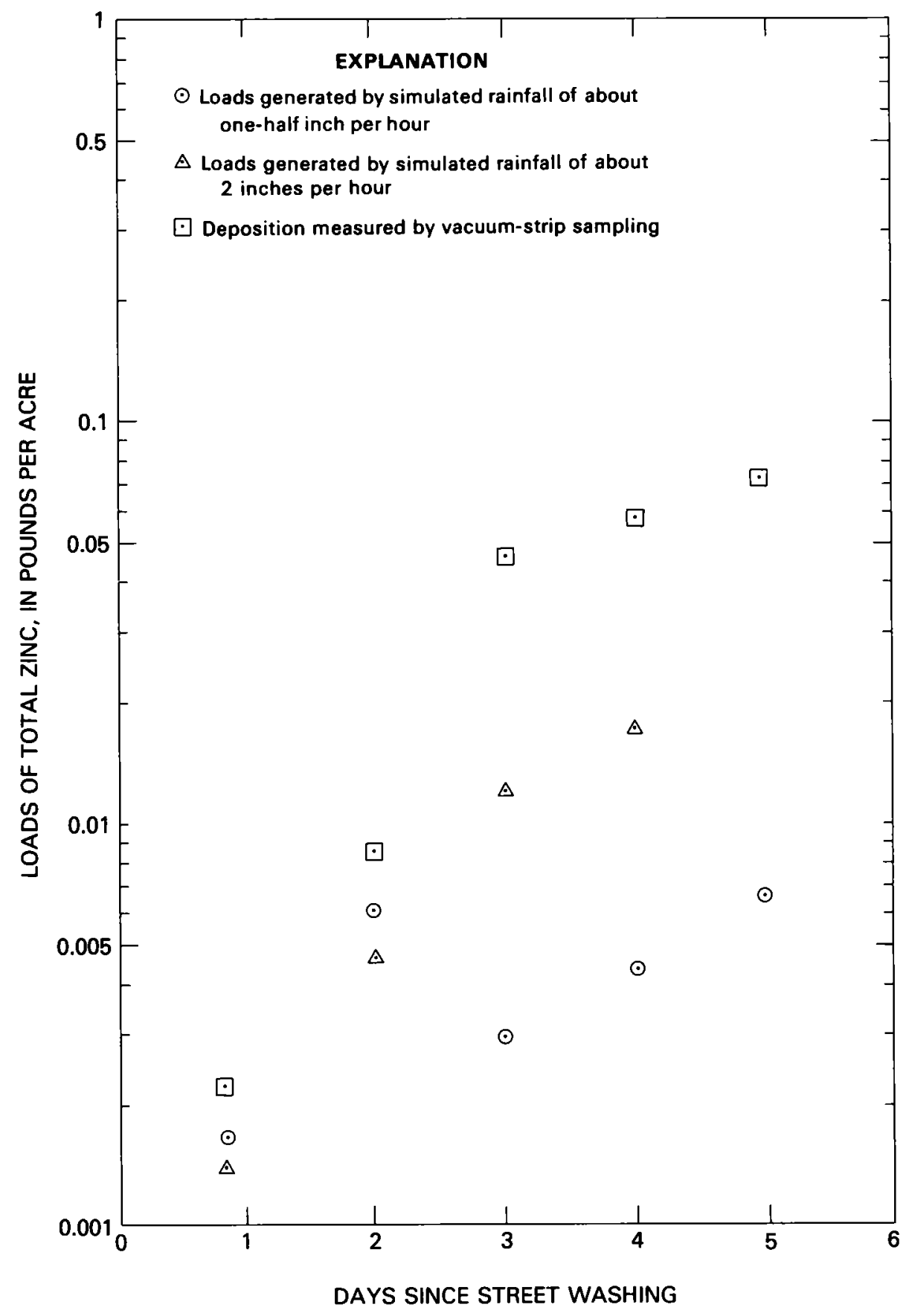

Figure 14.-Total zinc washoff loads and deposition measured by vacuum-strip sampling versus number of days since street washing for the Denver Federal Center plots, June 2-6, 1980.

This suggests that antecedent dry days may be more important in determining washoff loads of trace elements than of nutrients, however, this tendency was not substantiated in the data collected from a larger basin during the Denver urban runoff study (Ellis and Alley, 1979).
The event mean concentrations of the selected constituents in runoff from the rainfall simulations are generally much smaller than the event mean concentrations in storm runoff from the adjacent larger basin studied. The event mean concentrations in 
SIMULATED RAINFALL ON A STREET SURFACE

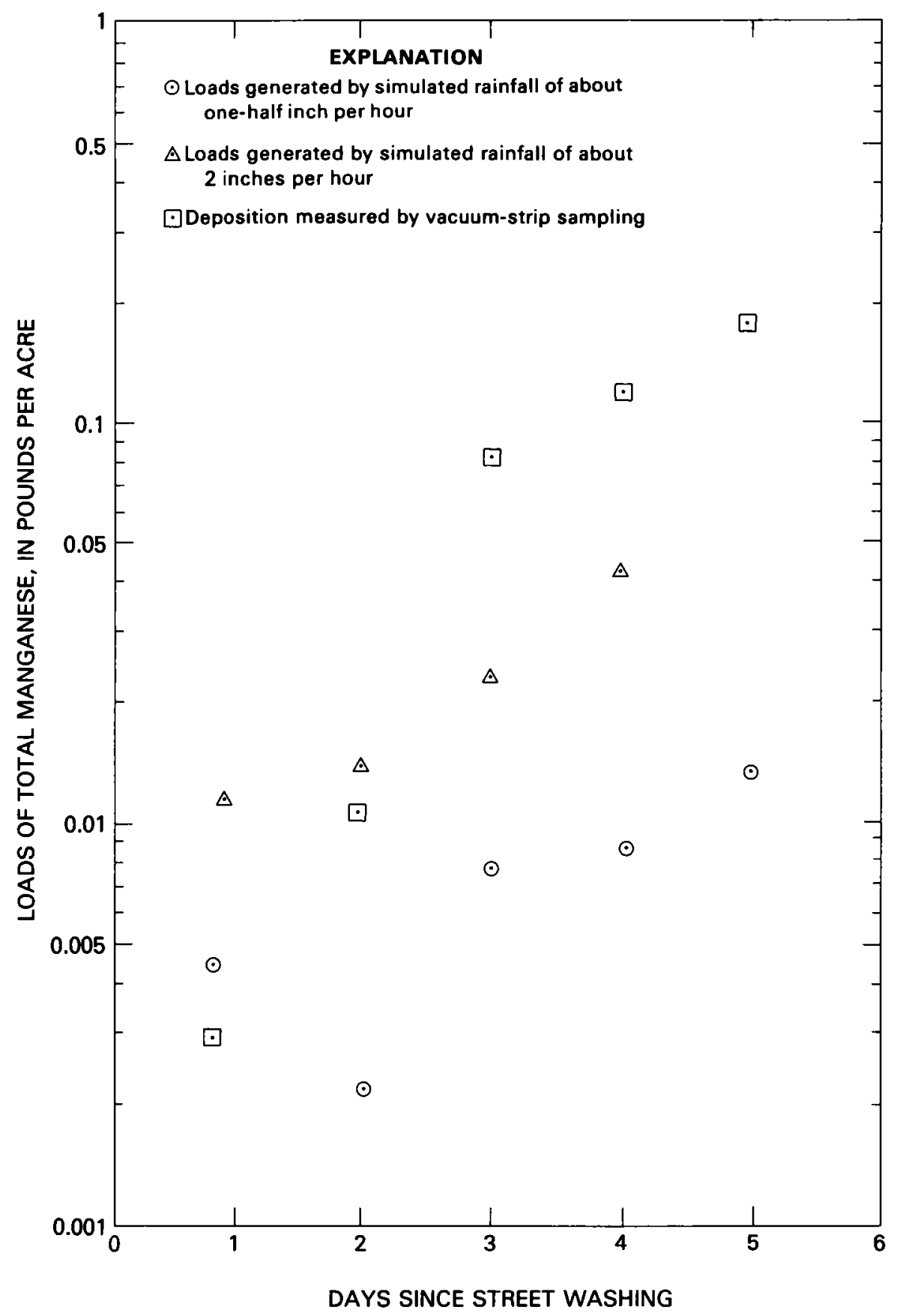

FIGURE 15.-Total manganese washoff loads and deposition measured by vacuum-strip sampling versus number of days since street washing for the Denver Federal Center plots, June 2-6, 1980.

runoff measured at station 06711635 North Avenue Storm Drain at the Denver Federal Center are summarized in table 4 by the maximum, minimum, and mean values for all storm runoff sampled in 1980 and 1981.

\section{CONSTITUENT DEPOSITION AND WASHOFF LOADS}

Constituent deposition was measured by three methods once a day for the 5 days following street 
RUNOFF CHARACTERISTICS AND WASHOFF LOADS, DENVER, COLORADO

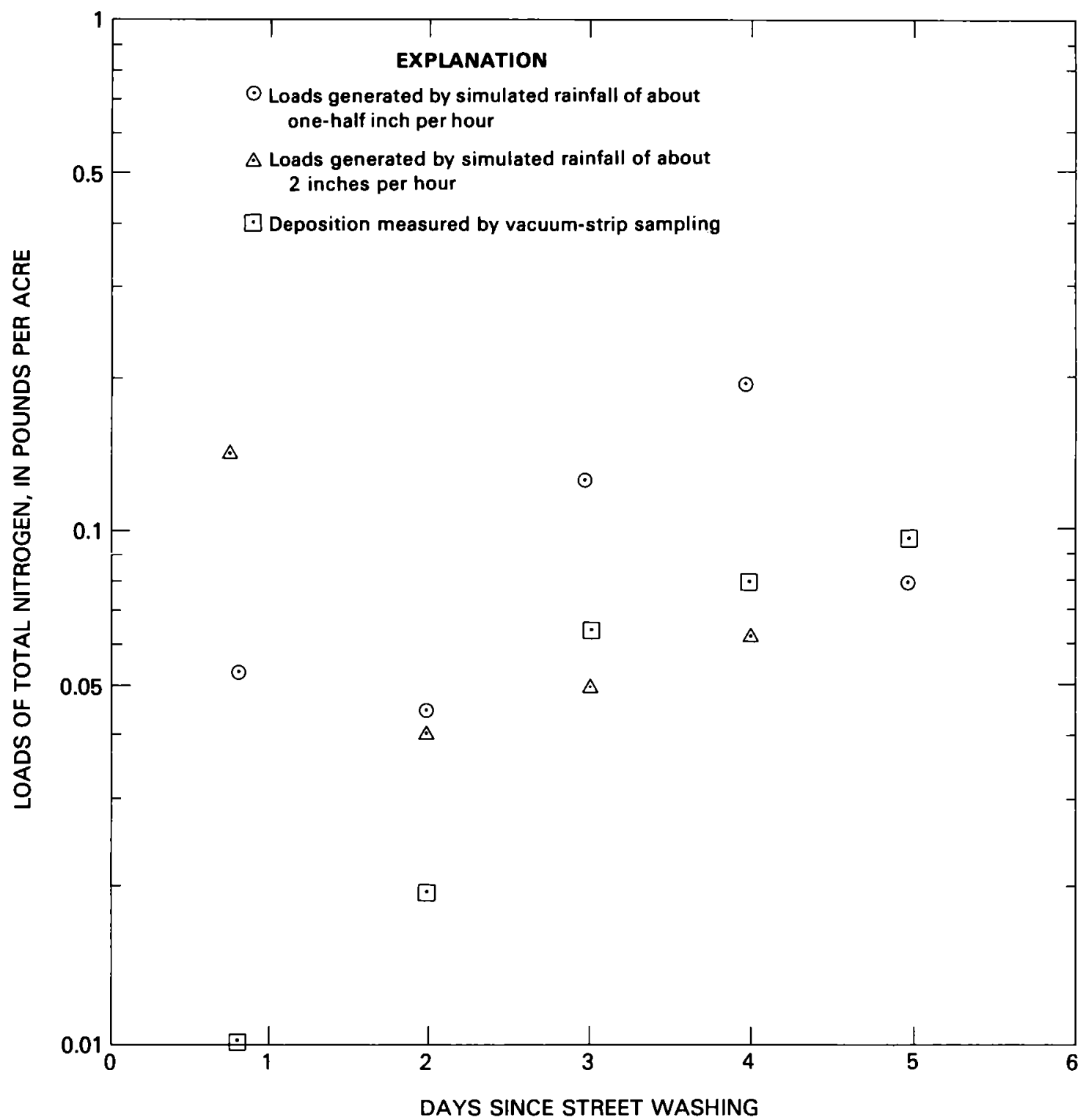

FIGURE 16.-Total nitrogen washoff loads and deposition measured by vacuum-strip sampling versus number of days since street washing for the Denver Federal Center plots, June 2-6, 1980.

TABLE 4.-Maximum, minimum, and mean event mean concentrations for all storm runoff sampled at station 06711635 North Avenue Storm Drain at the Denver Federal Center, at Lakewood in 1980 and 1981

[mg/L = milligrams per liter, $\mu g / L=$ micrograme per liter]

\begin{tabular}{|c|c|c|c|c|c|}
\hline $\begin{array}{l}\text { Constituent } \\
\text { (totels) }\end{array}$ & Units & Marimum & Minimum & Mean & $\begin{array}{l}\text { Number } \\
\text { of storms }\end{array}$ \\
\hline Suspended solids & $\mathbf{m g} / \mathbf{L}$ & 1,360 & 16 & 449 & 30 \\
\hline Lead & $\mu g / L$ & $\mathbf{5 5 0}$ & 80 & 310 & 31 \\
\hline$\ldots \ldots \ldots \ldots \ldots$ & $\mu \mathrm{g} / \mathrm{L}$ & 790 & 50 & 440 & 31 \\
\hline Manganese $\ldots \ldots \ldots \ldots \ldots \ldots \ldots$ & $\mu \boldsymbol{g} / \mathbf{L}$ & 950 & 50 & 410 & 31 \\
\hline Nitrogen $\ldots \ldots \ldots \ldots \ldots \ldots \ldots \ldots$ & $\mathbf{m g} / \mathbf{L}$ & 15 & 2.0 & 5.4 & 30 \\
\hline Phosphorus & $\mathbf{m g} / \mathbf{L}$ & 2.2 & .27 & .77 & 31 \\
\hline Organic carbon & $\mathbf{m g} / \mathbf{L}$ & 120 & 17 & 55 & 29 \\
\hline
\end{tabular}




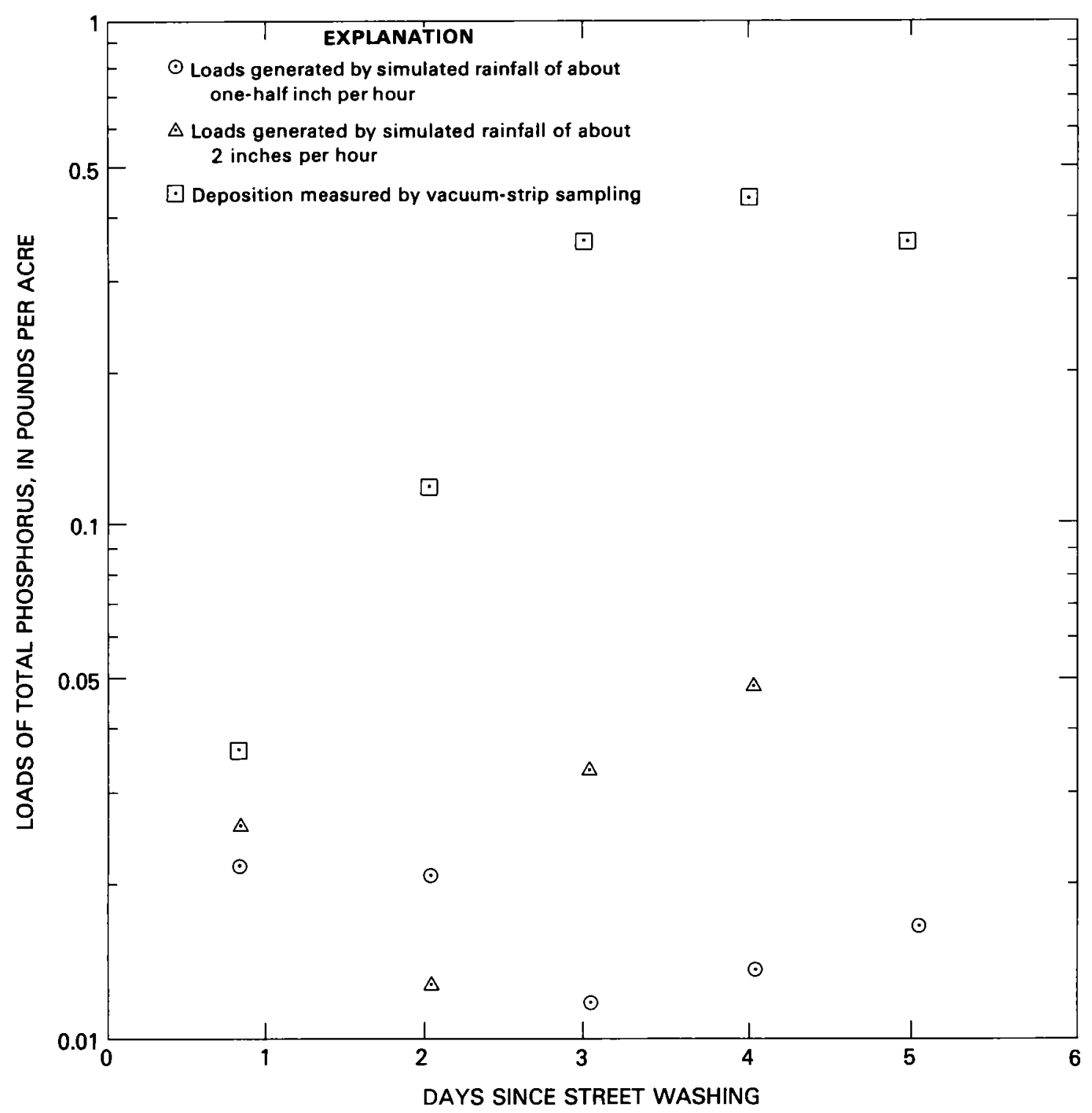

FIGURE 17.-Total phosphorus washoff loads and deposition measured by vacuum-strip sampling versus number of days since street washing for the Denver Federal Center plots, June 2-6, 1980.

washing. The three methods were vacuum-strip sampling, open-space bucket accumulation, and streetbucket accumulation. The amount of deposition measured using all three methods is shown in table 5. The values determined from vacuum-strip sampling were used in figures 12-17. The values determined by open-space bucket accumulation and by street-bucket accumulation are not shown in figures 12-18 because they are orders of magnitude smaller than either the washoff loads or the depositions measured by vacuumstrip sampling. Apparently the major source of constituents on the street surface is not conventional atmospheric deposition; this indicates that the traffic itself may be the major source. Traffic may contribute deposition to a street surface in several ways. One way is by tracking the transport of constituents into the study area from nearby areas by the action of vehicle tires. Another way is the direct depositing of 


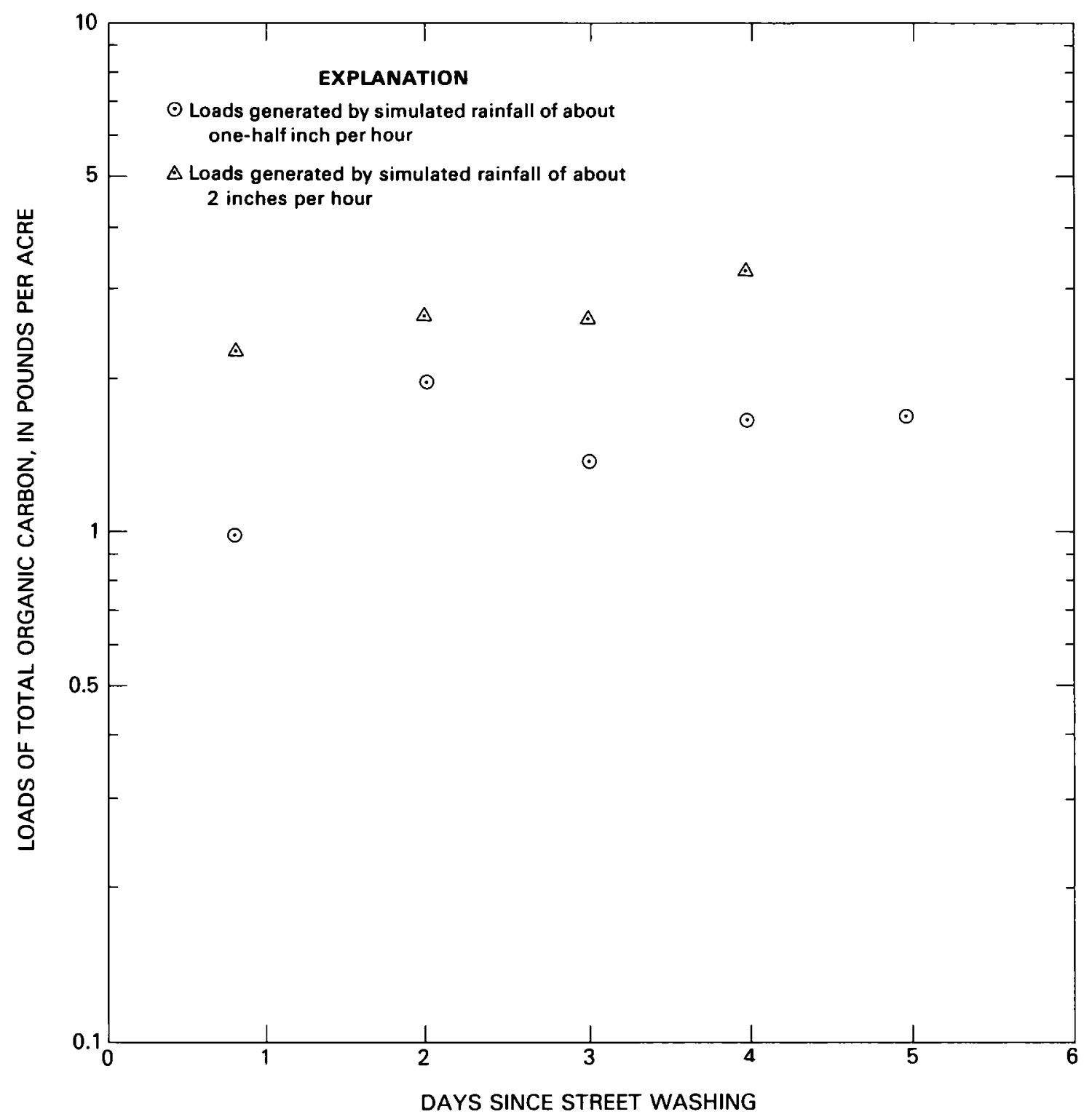

FIGURE 18.-Total organic carbon washoff loads versus number of days since street washing for the Denver Federal Center plots, June 2-6, 1980.

constituents on the street by exhaust emission. A third way traffic adds to deposition is by the physical action of the tires on the street surface, which erodes the surface, resulting in the production of fine particles which are available to be washed off by runoff.

The washoff loads normalized to area were generally smaller than the constituent deposition measured by vacuuming. Nitrogen washoff loads did not follow the same pattern, probably due to error introduced in calculating the washoff load. There was only a small difference between the concentrations in the applied water and the runoff (see page 12).

The vacuuming process has the ability to remove particles from the cracks and crevices that are not available to be washed off by runoff. Constituent deposition as measured by street vacuuming is considered to be the total load on a street surface, including that which is not available to be washed off by runoff. 
TABLE 5.-Deposition of selected water-quality constituents measured by vacuum-strip sampling, open-space bucket accumulation, and streetbucket accumulation on the Denver Federal Center plots

[In pounds por acre $\times 10^{-6}$ ]

\begin{tabular}{|c|c|c|c|c|c|c|c|c|}
\hline \multirow[b]{2}{*}{$\begin{array}{l}\text { Measuring } \\
\text { technique }\end{array}$} & \multirow{2}{*}{$\begin{array}{c}\text { Days } \\
\text { since } \\
\text { street } \\
\text { washing }\end{array}$} & \multicolumn{7}{|c|}{ Total } \\
\hline & & $\begin{array}{l}\text { suopended } \\
\text { solids }\end{array}$ & lead & zinc & manganoee & nitrogen & $\begin{array}{l}\text { phoo } \\
\text { phorus }\end{array}$ & $\begin{array}{l}\text { organic } \\
\text { carbon }\end{array}$ \\
\hline Vacuuming & 1 & $43,000,000$ & 14,000 & 2,200 & 3,000 & 10,000 & 37,000 & -- \\
\hline Open-space bucket & 1 & 1,400 & 1.3 & 4.4 & 1.1 & 65 & 4.4 & 160 \\
\hline Street bucket $\ldots \ldots \ldots$ & 1 & 3,100 & 1.0 & 2.7 & .91 & 150 & 2.7 & 16 \\
\hline Vacuuming & 2 & $130,000,000$ & 48,000 & 8,600 & 11,000 & 20,000 & 120,000 & -- \\
\hline Open-space bucket & 2 & 1,700 & 1.5 & 7.3 & 1.8 & -- & -- & 160 \\
\hline Street bucket .... & 2 & 2,600 & 2.3 & 9.2 & 2.7 & -- & -- & 300 \\
\hline Vacuuming & 3 & $690,000,000$ & 260,000 & 47,000 & 84,000 & 67,000 & 370,000 & -- \\
\hline Open-space bucket $\ldots \ldots \ldots \ldots \ldots \ldots \ldots$ & 3 & 2,000 & 1.9 & 4.6 & 2.7 & 29 & 3.7 & 470 \\
\hline Street bucket $\ldots \ldots \ldots \ldots \ldots \ldots \ldots \ldots$ & 3 & 3,800 & 5.7 & 1.0 & 5.5 & 60 & 18 & 230 \\
\hline Vacuuming & 4 & $750,000,000$ & 300,000 & 59,000 & 120,000 & 83,000 & 450,000 & -- \\
\hline Open-space bucket & 4 & 3,400 & 2.0 & 7.3 & 1.8 & 240 & 6.4 & 1,100 \\
\hline Street bucket .... & 4 & 12,000 & 13 & 13 & 14 & 180 & 34 & 170 \\
\hline Vacuuming & 5 & $750,000,000$ & 260,000 & 74,000 & 180,000 & 98,000 & 370,000 & - \\
\hline Open-space bucket & 5 & 4,400 & 2.3 & 4.8 & 2.3 & 49 & 5.5 & 1,100 \\
\hline Street bucket .... & 5 & 19,000 & 14 & 12 & 15 & 87 & 19 & 270 \\
\hline
\end{tabular}

\section{STATISTICAL ANALYSIS}

Selected constituent washoff loads were correlated with the number of days since street washing, intensity of rainfall, total rainfall, constituent deposition measured by open-space bucket accumulation and by street-bucket accumulation, and traffic count. The correlation coefficients are presented in table 6 . The variables were chosen because values of these variables can be obtained by simple techniques or from the literature. Gibbs and Doerfer (1982) present values of constituent deposition measured in the Denver metropolitan area. The number of days since street washing is analogous to antecedent dry days (the number of days since some predetermined rainfall, usually about 0.10 inch, fell) and is often used in theoretical load computations. Data from Denver urban studies have indicated that antecedent dry days are not an important consideration in actual loads in storm runoff from urban areas in semiarid climates. The deposition may be offset by some removal procedure, such as traffic or wind, causing the resultant accumulation rate to approach zero. Also, the previous rainfall may not have been sufficient to wash the accumulated deposition from the impervious surfaces, therefore, creating an uneven base upon which further accumulation could take place. Open-space bucket accumulation and street-bucket accumulation are roughly analogous to atmospheric deposition, depending on the placement of the collector. Although deposition measured by vacuum-strip sampling may be related to washoff loads, it was not used in the regression equations because there are generally no data currently available, except that collected during this experiment.

TABLE 6.-Correlation coefficients between selected waterquality constituent washoff loads and number of days since street washing, intensity of rainfalh, total rainfall, open-space constituent deposition, street constituent deposition, and traffic for the Denver Federal Center plots

\begin{tabular}{|c|c|c|c|c|c|c|}
\hline $\begin{array}{l}\text { Constituent } \\
\text { (totals) }\end{array}$ & $\begin{array}{c}\text { Days } \\
\text { since } \\
\text { street } \\
\text { waehing }\end{array}$ & $\begin{array}{c}\text { Intensity } \\
\text { of rainfall } \\
\text { (inches per } \\
\text { hour) }\end{array}$ & $\begin{array}{l}\text { Total } \\
\text { rainfall } \\
\text { (inchee) }\end{array}$ & $\begin{array}{c}\text { Open-space } \\
\text { deposition } \\
\text { (pounds per } \\
\text { acre) }\end{array}$ & $\begin{array}{c}\text { Street } \\
\text { deposition } \\
\text { (pounds per } \\
\text { acre) }\end{array}$ & $\begin{array}{c}\text { Traffic } \\
\text { (number } \\
\text { of } \\
\text { vehiclea) }\end{array}$ \\
\hline Suspended solids & 0.44 & 0.73 & 0.72 & 0.38 & 0.34 & 0.45 \\
\hline Lead & .43 & .61 & .63 & .38 & .51 & .44 \\
\hline Zinc & .54 & .59 & .58 & .40 & .61 & .54 \\
\hline Manganese & .43 & .73 & .74 & .19 & .49 & .44 \\
\hline Nitrogen & \multicolumn{6}{|c|}{ No significant relations } \\
\hline Phosphorus & .10 & .65 & .65 & .22 & .23 & .11 \\
\hline Organic carbon $\ldots \ldots \ldots \ldots \ldots$ & .16 & .89 & .90 & .25 & .12 & .15 \\
\hline
\end{tabular}


Correlation coefficients in columns 1 and 6 in table 6 are very similar because the number of days since street washing and the number of vehicles are related. Likewise, values in columns 2 and 3 are very similar because in this study rainfall intensity and total rainfall are related. Rainfall intensity and amount are the variables most highly correlated with washoff loads but are also highly correlated with each other in this study.

Regression analysis was used in an attempt to develop models to predict constituent washoff load from street surfaces in the Denver metropolitan area. The independent variables used in the analysis were total rainfall, rainfall intensity, and dry days. The logtransformed method and simple regression techniques were applied to the data. The results of the regression analysis were inconsistent with observations of the load graphs. Figures 3-11 indicate that both total rainfall and intensity of rainfall are important variables which must be independent of each other. In this experiment total rainfall and intensity of rainfall were highly correlated.

The design of the rainfall simulation precluded distinguishing whether total rainfall or intensity is the more important parameter. Analysis of figures 3-11 indicates that the intensity of rainfall is the more important parameter, but that after about 15-20 minutes most of the washoff had occurred. The total rainfall and intensity of the simulated rainfall are not representative of most natural rain storms monitored in the adjacent basin. Most storms monitored in the adjacent basin had total rainfalls of less than 0.20 inch (average storm rainfall was 0.22 inch) and rainfall intensities of less than 0.05 inch per hour (average rainfall intensity was about 0.06 inch per hour), and the average storm duration was about 3.5 hours. The rainfall simulation was not designed to simulate average rainfall storms in the Denver area.

\section{ROONEY RANCH SIMULATED RAINFALL-RUNOFF STUDY ON A NATIVE PASTURE}

\section{STUDY PLOTS}

Two plots at Rooney Ranch were artificially delineated by trenches and berms. An H-flume (Holtan and others, 1962) was installed at the outfall of each plot, which was approximately 400 square feet. Plot 1 had a slope of 0.20 and plot 2 a slope of 0.06 . Topographic maps of the two plots are presented in figure 19.

The plots were about 200 feet apart and about 1,000 feet downstream from monitoring station 06710610
Rooney Gulch at Rooney Ranch near Morrison. Although the two plots differed slightly in soil type and greatly in slope, both are representative of the clayey loam pastureland in the Rooney Gulch basin.

\section{DATA COLLEGTION METHODS}

In May 1981, two rainfall-simulation experiments were conducted on each of the two runoff plots. The paired experiments were conducted using different levels of antecedent soil moisture. Rainfall and runoff were measured and samples of runoff were collected throughout the runoff period for water-quality analysis. In addition, soil samples were collected before and after each experiment to characterize antecedent and resultant moisture contents.

\section{SIMULATED RAINFALL}

The rainfall was simulated by a system similar to that used at the Denver Federal Center site (see page 3). The setup of risers was a subset of the setup used at the Denver Federal Center site because the Rooney Ranch plots were smaller than the Denver Federal Center plots. A schematic is shown in figure 20. Hose supports were used to keep the supply lines from touching ground and restricting overland flow.

The intensity of the simulated rainfall during each experiment was about 2 inches per hour. The simulated rainfall in each plot was measured using 17 storage rain gages. The average rainfall was calculated as the average of the 17 measurements. Rainfall intensity was assumed to be constant.

\section{RUNOFF}

Runoff was measured volumetrically and samples for water-quality analysis of selected constituents were collected at the H-flume (Holtan and others, 1962). The constituents selected for analysis were the same as those selected in rainfall-simulation experiments conducted at the Denver Federal Center.

\section{SOIL MOISTURE}

Soil moisture samples were collected before and after each rainfall-simulation experiment. A 2-inch-diameter hand auger was used to collect samples at 3.9-inch increments to a depth of 11.8 inches. The samples were taken from locations adjacent to the plots until after 

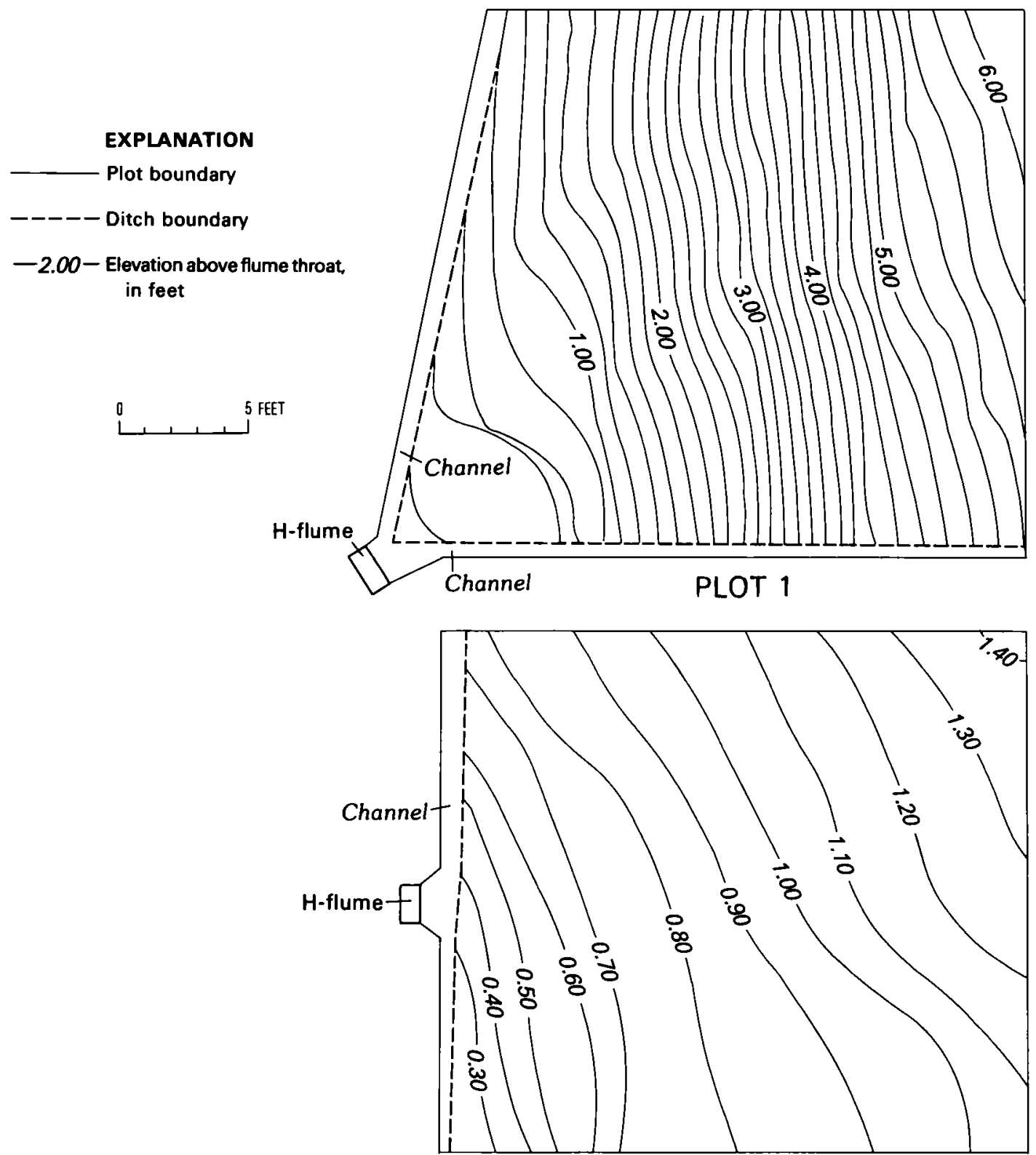

PLOT 2

Figure 19.-Topographic maps of plots 1 and 2 at the Rooney Ranch rainfall simulation site.

the second experiment at each plot to avoid disturbing the soil within the plot. Duplicate samples were collected after the first experiment on plot 1 to detect variations in soil moisture.

\section{RUNOFF QUANTITY}

Antecedent soil moisture, rainfall, and normalized runoff values, as well as ratios of normalized runoff to rainfall for the rainfall simulations and for natural storms at station 06710610 Rooney Gulch at Rooney Ranch, are shown in table 7. The runoff ratios for the natural storms ranged from 0.00 to 0.16 , whereas those for the simulated storms ranged from 0.01 to 0.08 . Because the ratio for natural storms is so variable, it is not possible to determine how good a predictor of the ratio the rainfall simulation data are; however, the ratios for the simulated rainfall experiments fall within the measured range of ratios for natural storms. The runoff 


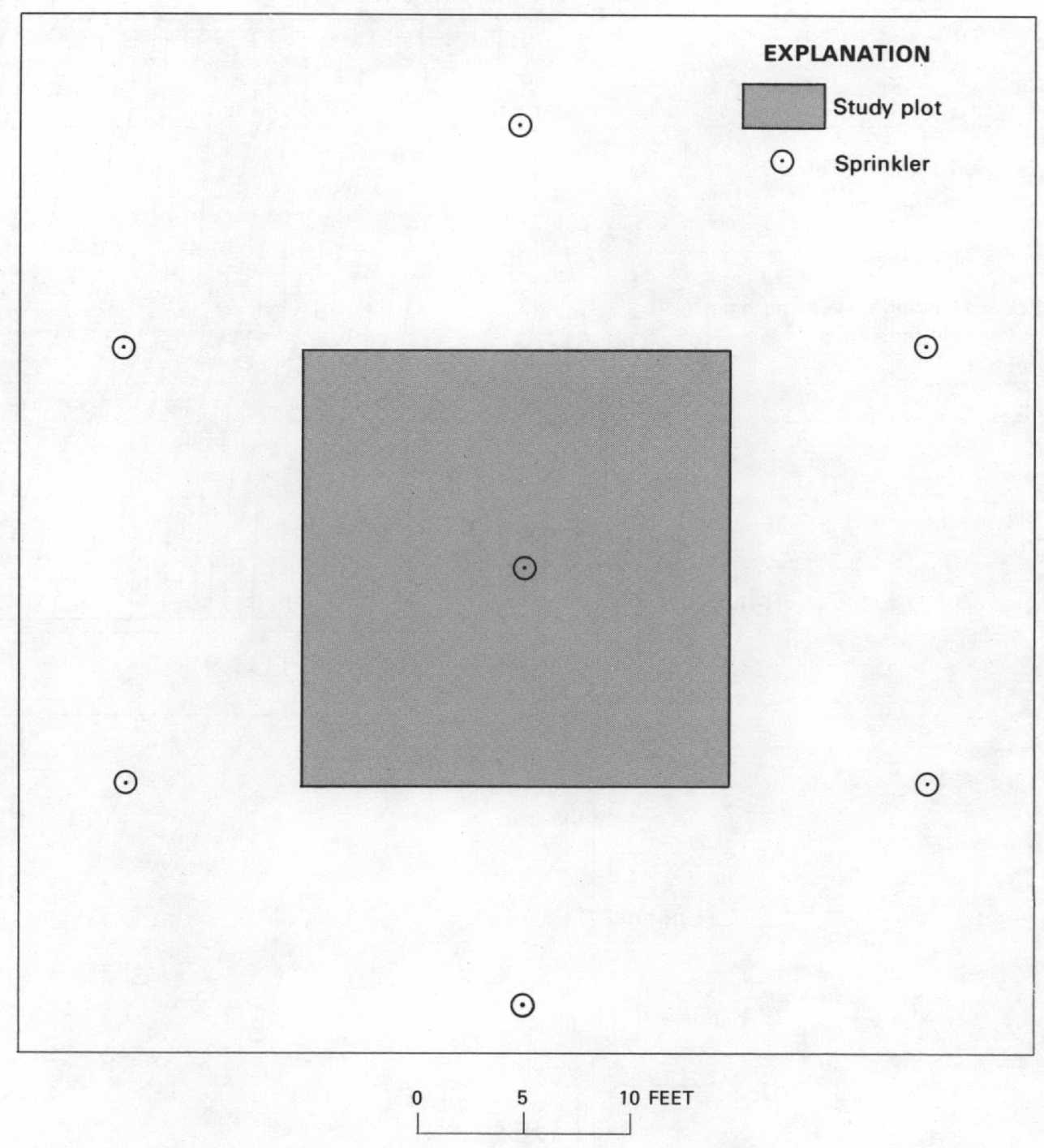

FIGURE 20.-Sprinkler layout at the Rooney Ranch plots.

ratios for the native pastureland are extremely low compared to the ratios for impervious areas. This indicates that runoff from pervious areas is generally negligible compared to runoff from impervious areas even when rainfall is intense and sustained and antecedent soil moisture is high. This inference applies only to areas of similar climate and soil types.

Flow on each plot occurred only in the humus during the first rainfall simulation. Overland flow on both plots was observed during the second experiment. This process was not observed during natural storms on the larger Rooney Gulch basin.

\section{INFILTRATION RATES}

Infiltration was calculated as the difference between rainfall and runoff, ignoring evapotranspiration. The magnitude of evapotranspiration is probably within the error of measurement for this study. The soil moisture data were not used to calculate infiltration because they were too variable and indicated a decrease in soil moisture after the last storm, which resulted in a negative infiltration value. The values of the density and moisture retention capability from the soil samples were used to characterize the soils at the sites (table 8). 
TABLE 7.-Antecedent soil moisture, rainfall, runoff, and runoff-to-rainfall ratios for the simulated rainstorms at Rooney Ranch and natural nainstorms at station 06710610 Rooney Gulch at Rooney Ranch, 1980 and 1981

\begin{tabular}{lcrrrrr}
\hline Plot & Storm & Simulated rainstorms at Rooney Ranch & $\begin{array}{c}\text { Antecedent } \\
\text { soil moisture } \\
\text { (pound/pound) }\end{array}$ & $\begin{array}{c}\text { Rainfall } \\
\text { (inchos) }\end{array}$ & $\begin{array}{c}\text { Runoff } \\
\text { (inches) }\end{array}$ & $\begin{array}{c}\text { Runoff-to } \\
\text { rainfall } \\
\text { ratio }\end{array}$ \\
\hline 1 & 1 & 0.22 & 1.19 & 0.03 & 0.03 \\
1 & 2 & .26 & 1.14 & .09 & .08 \\
2 & 1 & .34 & .91 & .01 & .01 \\
2 & 2 & .44 & .98 & .07 & .08 \\
\hline \multicolumn{7}{c}{} \\
\hline \multicolumn{7}{c}{ Natural rainstorms at station 06710610 Rooney Gulch at Rooney Ranch } \\
\hline
\end{tabular}

1980

April 23-24.

April 30-May 2

May 8-9 .

May 15-16

May 16-18

June 19-20

July 1-2

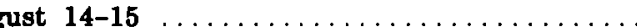

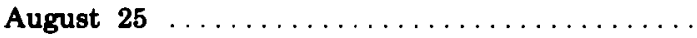

September 8-9 . . . . . . . . . . . . . . .

September 20

$\begin{array}{rrr}1.77 & 0.02 & 0.01 \\ 1.97 & .31 & .16 \\ .25 & .02 & .10 \\ .59 & .06 & .10 \\ .48 & .08 & .16 \\ .28 & .00 & .00 \\ .44 & .00 & .00 \\ .29 & .00 & .00 \\ .31 & .00 & .00 \\ .87 & .00 & .00 \\ .26 & .00 & .00\end{array}$

1981

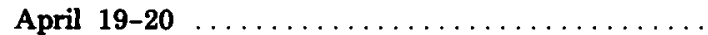

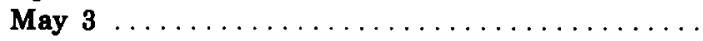

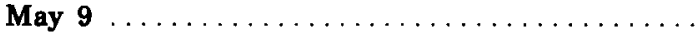

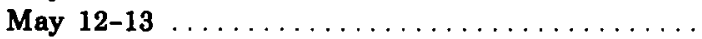

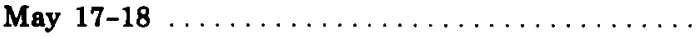

May 28-29 $\ldots \ldots \ldots \ldots \ldots \ldots \ldots \ldots \ldots \ldots \ldots \ldots$

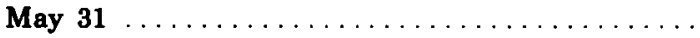

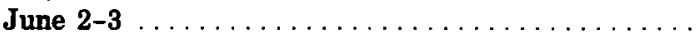

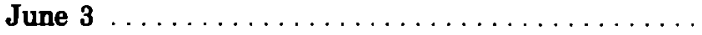

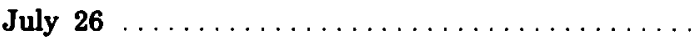

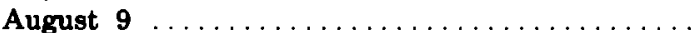

September $6-7 \ldots \ldots \ldots \ldots \ldots \ldots \ldots \ldots \ldots \ldots \ldots$

\begin{tabular}{rrr}
.71 & .00 & .00 \\
.45 & .00 & .00 \\
.36 & .00 & .00 \\
.67 & .00 & .00 \\
.91 & .01 & .01 \\
.87 & .00 & .00 \\
.31 & .00 & .00 \\
.30 & $<.01$ & $<.01$ \\
.42 & $<.01$ & $<.01$ \\
1.07 & .00 & .00 \\
.59 & .00 & .00 \\
.33 & .00 & .00 \\
\hline
\end{tabular}

The infiltration rates for individual storms are presented in figure 21 together with the normalized runoff hydrographs and precipitation graphs. The infiltration rate did not reach a steady-state value during any of the rainfall-simulation experiments, even after overland flow was observed, possibly because steady-state runoff was not sustained during the simulations.

\section{WATER-QUALITY RELATIONS}

Selected water-quality constituent loads from the Rooney Ranch rainfall-simulation experiments are shown in table 9. The percentage of the load of each constituent that was carried by the first 25 percent of the runoff is also shown. These loads ranged from 21 to 46 percent indicating that there is not a first flush of loads 

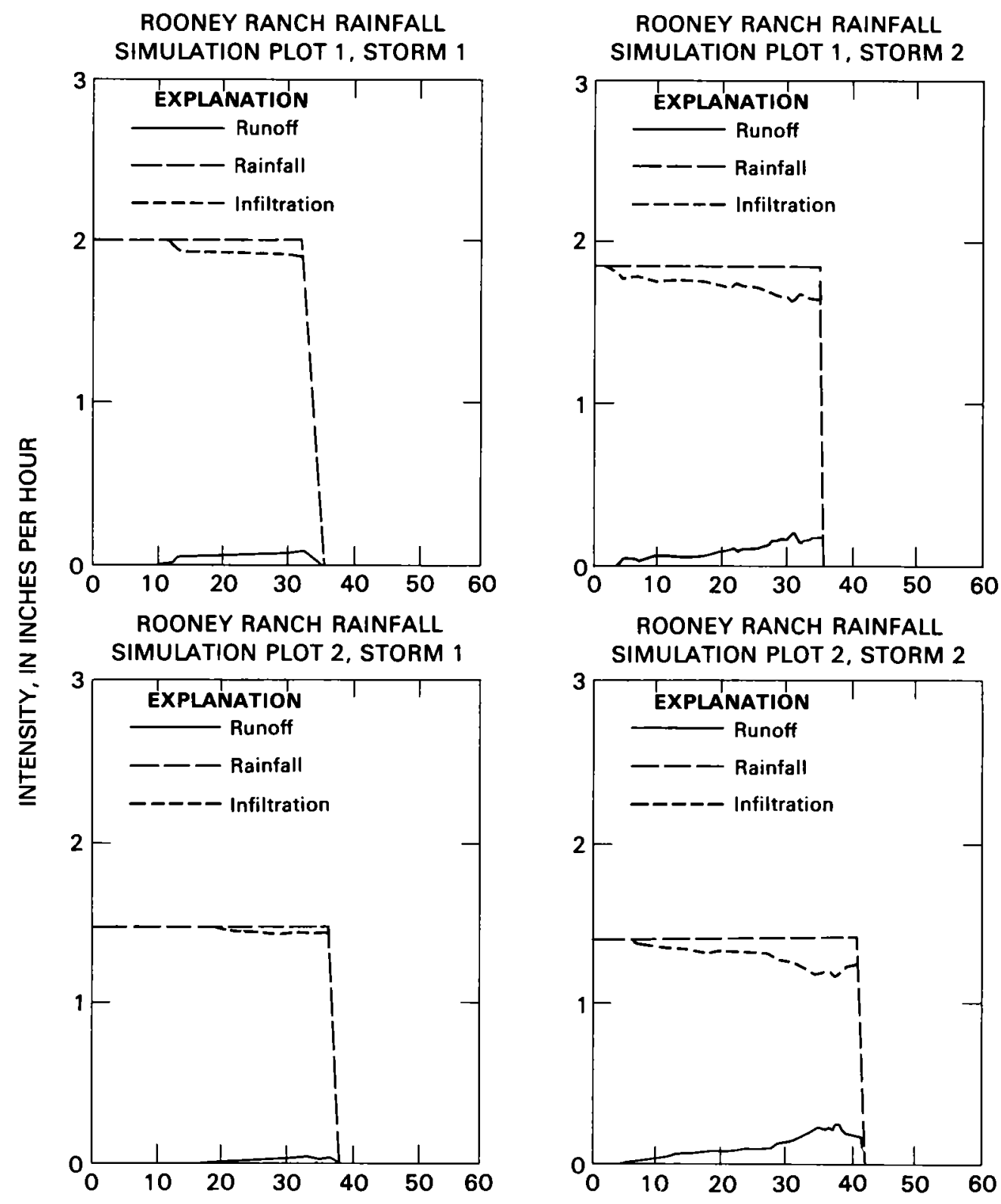

SIMULATION PLOT 2, STORM 2

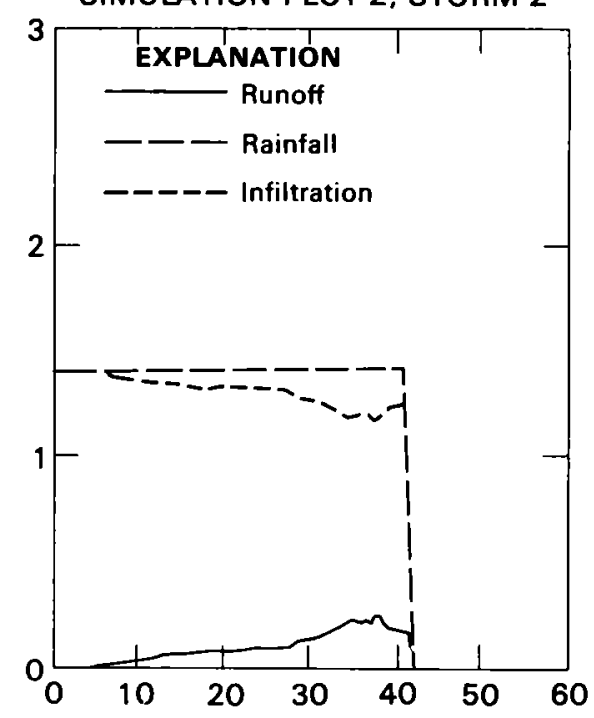

TIME, IN MINUTES SINCE START OF SIMULATED RAINFALL

FIGURE 21.-Rainfall, runoff, and infiltration versus time for the simulated rainfall storms at the Rooney Ranch plots, May 20, 1981.

(defined by 50 percent or higher) but that the first part of the runoff generally carried a higher proportion of the constituent loads than the remainder of the runoff. This compares with the 10 to 63 percent in the first quartile of runoff from natural storms at Rooney Gulch at Rooney Ranch.

The event mean concentrations of selected waterquality constituents are shown in table 10 . The range of event mean concentrations for natural storms producing runoff at station 06710610 Rooney Gulch at Rooney Ranch is shown for comparison. The event mean concentrations from the simulated rainfall storms are approximately an order of magnitude greater than the event mean concentrations for the natural storms producing runoff. This is in part due to the disturbance of the plot perimeters in constructing the small artificial drainage basins. An estimated 10 to 15 percent of the area of the runoff plots was disturbed by artifical boundary construction. The runoff from the disturbed area contributed additional sediment increasing the concentration of total suspended solids. Since the other constituents are highly correlated with total suspended 
TABLE 8.-Soil-moisture and bulk-density data for the Rooney Ranch rainfall simulation plots

\begin{tabular}{|c|c|c|c|c|c|c|c|c|}
\hline Plot & $\begin{array}{c}\text { Sample } \\
\text { hole }\end{array}$ & Time & $\begin{array}{c}\text { Depth } \\
\text { (inches) }\end{array}$ & $\begin{array}{c}\text { Volumetric } \\
\text { soil } \\
\text { water } \\
\text { content }\end{array}$ & $\begin{array}{c}\text { Average } \\
\text { volumetric } \\
\text { soil } \\
\text { water content } \\
\text { from } 0 \text { to } 11.8 \\
\text { incheg }\end{array}$ & $\begin{array}{l}\text { Moisture }{ }^{1} \\
\text { retantion } \\
\text { capability }\end{array}$ & $\begin{array}{c}\text { Bulk } \\
\text { density } \\
\text { (pounds per } \\
\text { cubic foot) }\end{array}$ & $\begin{array}{c}\text { Average } \\
\text { bulk density } \\
\text { for } 0 \text { to } \\
11.8 \text { inches } \\
\text { (pounds per } \\
\text { cubic foot) }\end{array}$ \\
\hline 1 & 1 & Before storm & $0.0-3.9$ & 0.20 & & 0.34 & 37 & \\
\hline 1 & 1 & do. & $3.9-7.9$ & .24 & 0.22 & .36 & 49 & 46 \\
\hline 1 & 1 & do. & $7.9-11.8$ & .23 & & .29 & 51 & \\
\hline 1 & 2 & do. & $7.9-11.8$ & .23 & & .33 & 72 & \\
\hline 1 & 23 & do. & $0.0-3.9$ & .27 & & .28 & 47 & \\
\hline 1 & 3 & do. & $3.9-7.9$ & .30 & .26 & .28 & 59 & 50 \\
\hline 1 & 3 & do. & $7.9-11.8$ & .21 & & .31 & 44 & \\
\hline 1 & 4 & After storm 2 & $0.0-3.9$ & .24 & & .28 & 43 & \\
\hline 1 & 4 & do. & $3.9-7.9$ & .27 & .29 & .25 & 59 & 58 \\
\hline 2 & 6 & Between storms & $0.0-3.9$ & .31 & & .35 & 46 & \\
\hline 2 & 6 & do. & $3.9-7.9$ & .53 & .44 & .36 & 84 & 71 \\
\hline 2 & 6 & do. & $7.9-11.8$ & .47 & & .34 & 84 & \\
\hline 2 & 7 & After storm 2 & $0.0-3.9$ & .24 & & .35 & 34 & \\
\hline 2 & 7 & do. & $3.9-7.9$ & .50 & .39 & .33 & 78 & 63 \\
\hline 2 & 7 & do. & $7.9-11.8$ & .43 & & .35 & 76 & \\
\hline
\end{tabular}

${ }^{1}$ See gloseary.

${ }^{2}$ Holes 2 and 3 are replicates.

solids, probably being attached to the sediment, the other concentrations were likewise increased. The waterquality concentrations during the rainfall simulation experiments are not considered representative of those from undisturbed pasture.

The constituent loads and event mean concentrations from plot 1 were significantly greater than those from plot 2. There are two possible explanations for this difference. First, plot 1 had a much greater slope than plot 2; plot 1 slope was 0.20 whereas plot 2 slope was 0.06 . The difference in slope would result in greater flow velocities on plot 1 , especially in the artificial drainage channels, resulting in greater total suspended solids loads. Since there was a high correlation between total suspended solids and the other constituents, the other constituents would likewise increase. Second, about 20 percent more water was applied to plot 1 than to plot 2. The greater amount of water applied to plot 1 than to plot 2 would have increased the sediment transport in the drainage channels as well as in the overland flow. The greater sediment transport from plot 1 than from plot 2 would again increase the constituent loads and concentrations for the above-stated reasons.

\section{CONCLUSIONS}

Runoff from simulated rainfall of two different intensities on a street showed higher runoff-to-rainfall ratios for the higher intensity simulated rainfall. A first flush of constituent loads occurred in the runoff from rainfall simulations on the street. However, no first flush occurred in the runoff from similar experiments on native grass covered plots.

The event mean concentrations of constituents in the runoff from simulated rainfall on the street were generally smaller than the event mean concentrations of constituents in the runoff from an adjacent urban basin. Comparison of results for the pasture plots and the natural basin are meaningless because the disturbance of the plots influenced the water quality of the runoff.

Observations of load graphs for the rainfall simulations on a street surface indicate that intensity of rainfall and total rainfall are important variables determining constituent loads. The design of the experiment was such that intensity of rainfall and total rainfall were highly correlated, thus precluding the development of useful regression equations to predict washoff loads. 
TABLE 9.-Loads of selected waterquality constituents and percentage of loads carried by the first 25 percent of the runoff from the Rooney Ranch rainfall simulation plots

[All units are in pounds. Percent of load carried by the first 25 percent of runoff is in parenthesis]

\begin{tabular}{|c|c|c|c|c|c|c|c|c|}
\hline \multirow[b]{2}{*}{ Plot } & \multirow[b]{2}{*}{ Storm } & \multicolumn{7}{|c|}{ Total } \\
\hline & & $\begin{array}{l}\text { suspended } \\
\text { solids }\end{array}$ & $\begin{array}{l}\text { lead } \\
\left(\mathbf{2 1 0 ^ { - 6 }}\right)\end{array}$ & $\underset{\left(x 10^{-6}\right)}{\operatorname{minc}}$ & $\begin{array}{c}\text { manganese } \\
\left(x 10^{-6}\right)\end{array}$ & $\begin{array}{c}\text { nitrogen } \\
\left(\times 10^{-3}\right)\end{array}$ & $\begin{array}{c}\text { phosphorus } \\
\left(\times 10^{-3}\right)\end{array}$ & $\begin{array}{l}\text { organic } \\
\text { carbon } \\
\left(x 10^{-8}\right)\end{array}$ \\
\hline $\mathbf{1}$ & 1 & 0.58 (29) & $14(30)$ & $34 \quad(31)$ & $170(31)$ & $1.3(33)$ & 0.18 (32) & $2.7(31)$ \\
\hline 1 & 2 & $1.3 \quad(30)$ & 27 (41) & 75 (36) & $360(36)$ & $2.8(36)$ & $.48(31)$ & 15 (28) \\
\hline 2 & 1 & $.097(46)$ & $2.1(27)$ & $6.9(31)$ & $31(35)$ & $.23(38)$ & $.017(35)$ & $1.3(31)$ \\
\hline 2 & 2 & $.30(42)$ & 11 (32) & $30(38)$ & $130(39)$ & $.86(45)$ & $.097(45)$ & $6.3(21)$ \\
\hline
\end{tabular}

TABLE 10.-Event mean concentrations of selected waterquality constituents in the runoff from simulated rainfall at Rooney Ranch and the range of event mean concentrations in the runoff from natural rainstorms at station 06710610 Rooney Gulch at Rooney Ranch [mg/L = milligrams per liter, $\mu \mathrm{g} / \mathrm{L}=$ micrograms per liter]

\begin{tabular}{|c|c|c|c|c|c|c|c|c|}
\hline \multirow[b]{2}{*}{ Plot } & \multirow[b]{2}{*}{ Storm } & \multicolumn{7}{|c|}{ Total } \\
\hline & & $\begin{array}{l}\text { suspended } \\
\text { solids } \\
\text { (mg/L) }\end{array}$ & 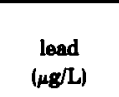 & $\begin{array}{c}\text { zinc } \\
(\mu g / L)\end{array}$ & $\begin{array}{c}\text { manganese } \\
\text { (mg/L) }\end{array}$ & $\begin{array}{l}\text { nitrogen } \\
\text { (mg/L) }\end{array}$ & $\begin{array}{l}\text { phoaphorus } \\
\text { (mg/L) }\end{array}$ & $\begin{array}{l}\text { organic } \\
\text { carbon } \\
\text { (mg/L) }\end{array}$ \\
\hline 1 & 1 & 8,500 & 200 & 500 & 2,500 & 18 & 2.6 & 40 \\
\hline 1 & 2 & 6,900 & 140 & 400 & 1,900 & 15 & 2.6 & 79 \\
\hline \multicolumn{9}{|c|}{ Natural rainfall } \\
\hline \multirow{2}{*}{\multicolumn{2}{|c|}{$\begin{array}{l}\text { Range }{ }^{1} \\
\text { Mean }^{1}\end{array}$}} & $79-870$ & $9.8-150$ & $40-180$ & $180-1,200$ & $1.4-6.1$ & $0.14-.66$ & $13-28$ \\
\hline & & 260 & 25 & 87 & 350 & 2.1 & 0.27 & 21 \\
\hline
\end{tabular}

\footnotetext{
${ }^{1}$ The range of values and mean are given only for atorms producing runoff (See table 7 ).
}

Simulated rainfall on small pasture plots produced runoff-to-rainfall ratios similar to runoff-to-rainfall ratios from a larger native pasture subjected to natural rainfall.

\section{REFERENCES}

Ellis, S.R., and Alley, W.M., 1979, Quantity and quality of urban runoff from three localities in the Denver metropolitan area, Colorado: U.S. Geological Survey Water-Resources Investigations Report 79-64, $60 \mathrm{p}$.

Ellis, S.R., Doerfer, J.T., Mustard, M.H., Blakely, S.R., and Gibbs, J.W., 1984, Analysis of urban storm-runoff data and the effects on the South Platte River, Denver metropolitan area, Colorado: U.S. Geological Survey Water-Resources Investigations Report 84-4159, 66 p.

Gibbs, J.W., 1981, Hydrologic data for urban storm runoff from nine sites in the Denver metropolitan area, Colorado: U.S. Geological Survey Open-File Report 81-682, 142 p.
Gibbs, J.W., and Doerfer, J.T., 1982, Hydrologic data for urban storm runoff in the Denver metropolitan area, Colorado: U.S. Geological Survey Open-File Report 82-872, 560 p.

Holtan, H.N., Minshall, N.E., and Harold, L.L., 1962, Field manual for research in agricultural hydrology: Agricultural Handbook No. 224, U.S. Department of Agriculture, Agricultural Research Service, 215 p.

Lindsay, W.L., and Norvell, W.A., 1978, Development of a DTPA soil test for zinc, iron, manganese, and copper: Soil Science Society of America Journal, v. 42, no. 3, p. 421-428.

Linsley, R.K., and Franzini, J.B., 1972, Water-resources engineering (2d ed.): New York, McGraw-Hill Book Co., 690 p.

Lusby, G.C., 1977, Determination of runoff and sediment yield by rainfall simulation, in Erosion: Research Techniques, Erodibility, and Sediment Delivery, Geophysical Abstracts, Ltd., Norwich, England, p. 19-30.

Miller, R.F., and McQueen, I.S., 1978, Moisture relations in rangelands, Western United States, in Proceedings of the first International Rangeland Congress: p. 318-321.

U.S. Geological Survey, 1979, Techniques of water-resources investigations of the United States Geological Survey, Book 5, Chapter A1, 626 p. 